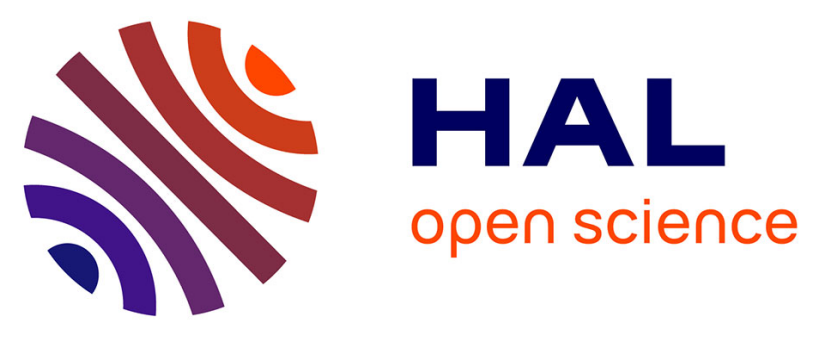

\title{
Design, synthesis and anticancer properties of Iso CombretaQuinolines as potent tubulin assembly inhibitors
}

\author{
Ilhem Khelifi, Timothée Naret, Dolor Renko, Abdallah Hamze, Guillaume \\ Bernadat, Jérôme Bignon, Christine Lenoir, Joëlle Dubois, Jean-Daniel Brion, \\ Olivier Provot, et al.
}

\section{To cite this version:}

Ilhem Khelifi, Timothée Naret, Dolor Renko, Abdallah Hamze, Guillaume Bernadat, et al.. Design, synthesis and anticancer properties of Iso CombretaQuinolines as potent tubulin assembly inhibitors. European Journal of Medicinal Chemistry, 2017, 127, pp.1025-1034. 10.1016/j.ejmech.2016.11.012 . hal-02394312

\section{HAL Id: hal-02394312 https://hal.science/hal-02394312}

Submitted on 4 Dec 2019

HAL is a multi-disciplinary open access archive for the deposit and dissemination of scientific research documents, whether they are published or not. The documents may come from teaching and research institutions in France or abroad, or from public or private research centers.
L'archive ouverte pluridisciplinaire HAL, est destinée au dépôt et à la diffusion de documents scientifiques de niveau recherche, publiés ou non, émanant des établissements d'enseignement et de recherche français ou étrangers, des laboratoires publics ou privés. 


\title{
Design, Synthesis and Anticancer Properties of IsoCombretaQuinolines as Potent Tubulin Assembly Inhibitors
}

Ilhem Khelifi, ${ }^{\text {a }}$ Timothée Naret, ${ }^{\text {a }}$ Dolor Renko, ${ }^{\text {a }}$ Abdallah Hamze, ${ }^{\text {a }}$ Guillaume Bernadat, ${ }^{\mathrm{a}}$ Jérome Bignon, ${ }^{\mathrm{b}}$ Christine Lenoir, ${ }^{\mathrm{b}}$ Joëlle Dubois, ${ }^{\mathrm{b}}$ Jean-Daniel Brion ${ }^{\mathrm{a}}$, Olivier Provot, ${ }^{* a}$ Mouad Alami*a

${ }^{a}$ BioCIS, Univ. Paris-Sud, CNRS, Université Paris-Saclay, 92290, Châtenay-Malabry, France

${ }^{b}$ Institut de Chimie des Substances Naturelles, UPR 2301, CNRS avenue de la terrasse, F-91198 Gif sur Yvette, France

${ }^{*}$ Corresponding authors. Tel.: +33 1468358 47. Fax: +33 1468358 28. Email: olivier.provot@u-psud.fr (O.P.) and/or mouad.alami@u-psud.fr (M.A.)

\begin{abstract}
The synthesis and evaluation of a new series of IsoCombretaQuinolines (IsoCoQuines) 2 with a 2-substituted-quinoline in place of the 3,4,5-trimethoxyphenyl ring present in isoCA-4 and CA-4 are described. Most of these compounds displayed a potent cytotoxic activity $\left(\mathrm{IC}_{50}<10 \mathrm{nM}\right)$ against a panel of five human cancer cell lines and inhibited tubulin assembly at a micromolar level. The most potent analogue $\mathbf{2 b}$, having a 3-hydroxy-4-methoxyphenyl as B-ring, led to cell cycle arrest in G2/M phase. Docking studies indicate that $\mathbf{2 b}$ showed a binding mode comparable to those previously observed with quinazoline analogous (IsoCoQ) and with isoCA-4 at the colchicine binding site of tubulin.
\end{abstract}

Keywords: Cancer, quinoline, isoCA-4, cytotoxicity, tubulin, binding. 


\section{Introduction}

Combretastatin A-4 (CA-4) has been isolated from the African willow tree, Combretum caffrum by Pettit and coworkers [1] in 1989. This (Z)-stilbene was found to be a potent anticancer agent which affect microtubule dynamics. CA-4 inhibit the assembly of tubulin by binding to the colchicine site.[2] Besides its anti-tubulin activity, CA-4 displayed a potent cytotoxicity at a nanomolar level against a wide range of human cancer cells including multidrugs resistant (MDR) cells.[3] Moreover, it has been demonstrated that CA-4 displayed a selective toxicity towards the vascular network of tumors, inducing an irreversible shutdown of blood flow to neoplastic cells. [4] Currently, a watersoluble prodrug, CA-4P (fosbretabulin, Zybrestat ${ }^{\mathrm{TM}}$ ) [5] has received in 2016 orphan drug status (USA and Europe) to treat neuroendocrine tumors (NETs) and glioblastoma multiform (GBM).[6] However, CA-4 and its prodrugs are unstable since the $(Z)$-stilbene is prone to isomerization to provide the 100 -fold less active $E$-isomer during storage, administration and metabolization.[7, 8] This problem and the structural simplicity of CA-4 encouraged the scientific community these last decades to synthesize a large number of stable CA-4 analogues, mainly by including the double bond into cycles and heterocycles.[9, 10] Moreover, numerous modifications on the B-ring of CA-4 and its analogues have been achieved to improve activity or solubility of novel classes of ligands. Our group, in an ongoing project aimed to develop stable CA-4 analogues[11], has recently definitively solved the stability problem of CA-4 by the discovery and the synthesis of isoCA-4, the 1,1-diarylethylene non-natural isomer of CA-4 which holds similar biological properties as CA-4.[12, 13]. This compound which was easily synthesized in four steps was shown to be chemically [14] and metabolically stable[15]. We have also prepared a large variety of new bioactive analogues by chemical modifications on the B-ring of isoCA-4, and identified other stable and promising antiproliferative agents such as iso $\mathrm{NH}_{2} \mathrm{CA}-4$, isoFCA-4,[16] or naphthyl,[17] chromen[18] and benzoxepin derivatives.[19] We are now interested in identifying novel potent drugs as isoCA-4 analogues by replacing the "traditional" 3,4,5-trimethoxyphenyl unit (A-ring) by nitrogen containing heterocycles. It should be noted that, in the CA-4 series, the replacement of the 3,4,5trimethoxyphenyl A-ring [20, 21, 22] which is "crucial to obtain relevant cytotoxic and antitubulin responses"'[9], by heterocyclic derivatives has received very little attention. Very recently, we have demonstrated for the first time, that changing the 3,4,5-trimethoxyphenyl A-ring by a quinazoline nucleus resulted in a novel series of antimitotic drugs,[23] with isoCoQ 1 as a lead compound, displaying a nanomolar level of cytotoxicity against various tumor cells. The possible binding mode on tubulin of the more potent quinazolines was studied and indicate that the N-1 atom of such quinazolines interacted with Cys $\beta 241$ of tubulin whereas the position of the N-3 atom of these drugs was inadequate to interact with tubulin. On the basis of these observations, we were interested to synthesize other nitrogen containing heterocycles as A ring and particularly isocombretaquinolines (isoCoQuines[24]) of type 2 (Figure 1) to evaluate their biological activities. Preliminary in vitro cytotoxicity and inhibition of tubulin assembly of novel nitrogen-containing heterocycles (quinolines $\mathbf{2 a - c}$ and $\mathbf{2 g - n}$, isoquinoline $\mathbf{2 d}$ and quinoxaline $\mathbf{2 e}$ ) will be presented and discussed. The possible binding mode of the more bioactive substrate isoCoQuine $\mathbf{2 b}$ and its superimposition with isoCA-4 on tubulin is also reported.

Figure 1. Structures of CA-4 and water soluble prodrugs, isoCA-4 and analogues, isoCoQ $\mathbf{1}$ and target isoCoQuines 2.

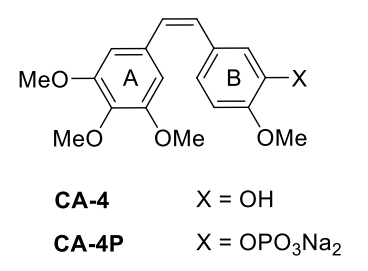

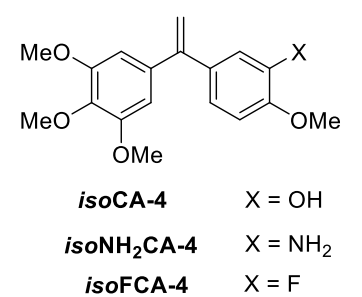

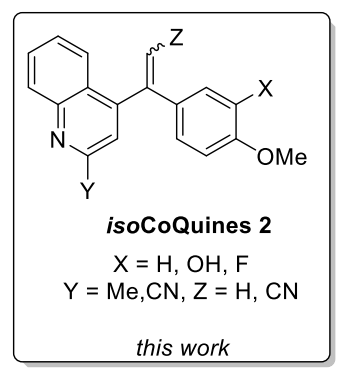




\section{Results and discussion}

\subsection{Chemistry.}

The synthesis of the targets isoCoQuines 2a-c bearing a 3,4-disubstituted B-ring and having a great resemblance with isoCA-4, and isoFCA-4 were prepared from 4-chloroquinaldine which was coupled in a sealed tube with a variety of $N$ tosylhydrazones 3a-c in the presence of $\mathrm{PdCl}_{2}\left(\mathrm{CH}_{3} \mathrm{CN}\right)_{2}$ as the catalyst,[25] 1,1'-bis(diphenylphosphino)ferrocene (dppf) as the ligand, $\mathrm{LiOtBu}\left(2.2\right.$ equiv) as the base at $100{ }^{\circ} \mathrm{C}$. Similarly, isoquinoline $\mathbf{2 d}$ and quinoxaline derivative $2 \mathbf{e}$ were prepared from $N$-tosylhydrazone 3a which reacted with 1-chloro-3-methylisoquinoline and 2-chloro-3methylquinoxaline respectively, to furnish $\mathbf{2 d}$ and $\mathbf{2 e}$ with satisfactory yields. One can note that the replacement of dppf by di- $t \mathrm{Bu}$ (methyl)phosphonium tetrafluoroborate $\left(\left[(t \mathrm{Bu})_{2} \mathrm{MePH}\right] \mathrm{BF}_{4}\right)$ as the ligand for the coupling of 2-chloro-3methylquinoxaline with 3a slightly improved the yield of $2 \mathbf{e}(65 \%$ vs $57 \%)$. Using this ligand in place of dppf for the coupling of 1-chloro-3-methylisoquinoline with $\mathbf{3 a}$ was totally unsuccessful. To introduce some functionalities on the C-2 of quinaldines 2 in place of the methyl substituent, we have synthesized 4-chloro-2-cyanoquinoline 4 from 2,4dichloroquinoline and $\mathrm{Zn}(\mathrm{CN})_{2}$ in the presence of $\mathrm{Pd}\left(\mathrm{PPh}_{3}\right)_{4}$ in DMF. Using these experimental conditions, quinoline 4 was obtained with a good yield of $70 \%$ and with a total selectivity since only the chlorine atom on C-2 was substituted by a $\mathrm{CN}$ group.
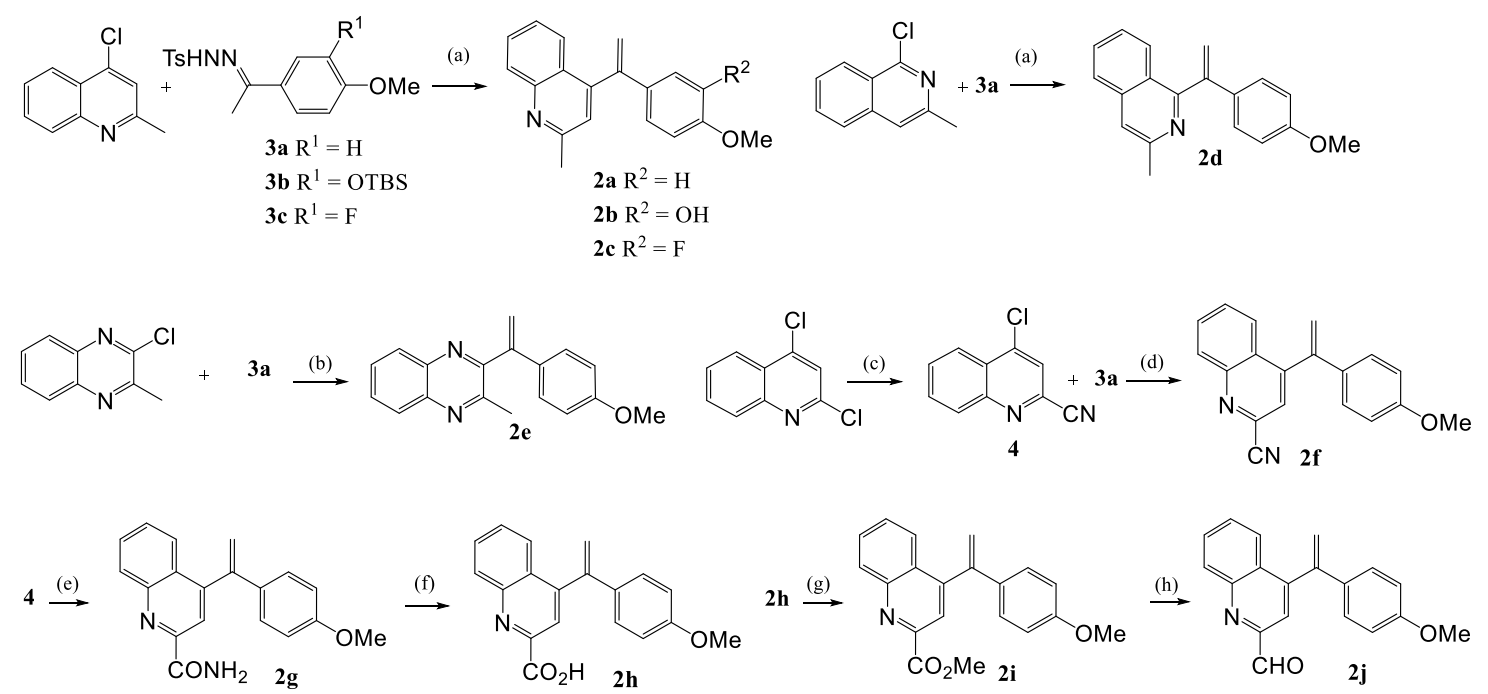<smiles>C=C(c1ccc(OC)cc1)c1cc(CO)nc2ccccc12</smiles><smiles>C=C(c1ccc(OC)cc1)c1cc(C(F)(F)F)nc2ccccc12</smiles><smiles>COc1ccc(C(=O)c2cc(C)nc3ccccc23)cc1</smiles><smiles>COc1ccc(C(=CC#N)c2cc(C)nc3ccccc23)cc1</smiles>

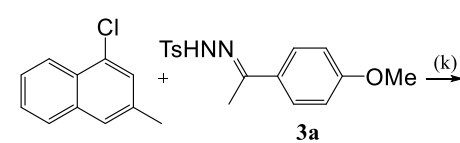<smiles>C=C(c1ccc(OC)cc1)c1cc(C)cc2ccccc12</smiles>

Scheme 1. Synthesis of target compounds $2 \mathrm{a}-\mathrm{n}$ a Reagents and conditions: (a) $\mathrm{PdCl}_{2}\left(\mathrm{CH}_{3} \mathrm{CN}\right)_{2}(10 \mathrm{~mol} \%)$, dppf (20 mol\%), dry LiOtBu (2.2 equiv), Ntosylhydrazone (1.5 equiv), dioxane, $100{ }^{\circ} \mathrm{C}$, sealed tube. (b) $\mathrm{PdCl}_{2}\left(\mathrm{CH}_{3} \mathrm{CN}\right)_{2}(10 \mathrm{~mol} \%)$, $\left[(\mathrm{tBu})_{2} \mathrm{MePH}\right] \mathrm{BF}_{4}(20 \mathrm{~mol} \%)$, LiOtBu (2.2 equiv), dioxane, $100{ }^{\circ} \mathrm{C}$, sealed tube (c) $\mathrm{Zn}(\mathrm{CN})_{2}$ (0.5 equiv), $\mathrm{Pd}\left(\mathrm{PPh}_{3}\right)_{4}(10 \mathrm{~mol} \%)$, DMF, $90{ }^{\circ} \mathrm{C}$ (d) $\mathrm{PdCl}_{2}\left(\mathrm{CH}_{3} \mathrm{CN}\right)_{2}(10 \mathrm{~mol} \%)$, dppf (20 mol\%), dry LiOtBu (1.8 equiv), $N$-tosylhydrazone (1.5 equiv), dioxane, $100{ }^{\circ} \mathrm{C}$, sealed tube, 3 h. (e) $\mathrm{PdCl}_{2}\left(\mathrm{CH}_{3} \mathrm{CN}\right)_{2}(10 \mathrm{~mol} \%)$, dppf (20 mol\%), LiOtBu (3.6 equiv), dioxane, $100{ }^{\circ} \mathrm{C}$, sealed tube. (f) $\mathrm{NaOH}, 100{ }^{\circ} \mathrm{C}$, sealed tube (g) $\mathrm{SOCl}_{2}, \mathrm{MeOH},-5{ }^{\circ} \mathrm{C}$ to $55^{\circ} \mathrm{C}$. (h) DIBAL (1 equiv), $\mathrm{CH}_{2} \mathrm{Cl}_{2},-78{ }^{\circ} \mathrm{C}$. (i) $\mathrm{O}_{3}, \mathrm{PPh}_{3}(2$ equiv), $\mathrm{MeOH},-78^{\circ} \mathrm{C}$. (j) $\mathrm{PO}(\mathrm{OEt})_{2} \mathrm{CH}_{2} \mathrm{CN}$ (2 equiv), LiHMDS (2 equiv), THF, $0{ }^{\circ} \mathrm{C}$ to reflux. (k) $\mathrm{Pd}_{2} \mathrm{dba}_{3} \cdot \mathrm{CHCl}_{3}(2.5 \mathrm{~mol} \%$ ), XPhos (10 mol\%), $\mathrm{LiOtBu}$ (2.2 equiv), $N$-tosylhydrazone ( 1.5 equiv), dioxane, $100^{\circ} \mathrm{C}$, microwave irradiation. 
The 2-cyano-4-chloroquinoline 4 was then successfully coupled in the presence of dry $\mathrm{LiO} t \mathrm{Bu}(1.8$ equiv) with hydrazone 3a to provide isoCoQuine 2f. IsoCoQuine $\mathbf{2 g}$ bearing a $\mathrm{CONH}_{2}$ function on C-2 was successfully prepared (70\%) by using similar coupling conditions between $N$-tosylhydrazone $\mathbf{3 a}$ and the cyano derivative $\mathbf{4}$ using an excess of $\mathrm{LiO} t \mathrm{Bu}$ (3.6 equiv) in 1,4-dioxane. In this case and beside the expected Pd-coupling reaction, we were pleased to also observe a total hydration of the nitrile group providing the amide compound 2g.[26] This later was transformed into its corresponding carboxylic acid $\mathbf{2 h}$ using $\mathrm{NaOH}$ at $100{ }^{\circ} \mathrm{C}$ (63\%) and into ester $\mathbf{2 i}$ using $\mathrm{SOCl}_{2}$ in $\mathrm{MeOH}^{\text {[27] }}$ IsoCoQuine $\mathbf{2} \mathbf{j}$ was prepared from the DIBAL-reduction of the ester $\mathbf{2} \mathbf{i}$ and a subsequent DIBAL-reduction of $\mathbf{2} \mathbf{j}$ furnished isoCoQuine $2 \mathbf{k}$ having a $\mathrm{CH}_{2} \mathrm{OH}$ function on $\mathrm{C}-2$ of quinoline nucleus. Quinoline 2l, having a $\mathrm{CF}_{3}$ group on C-2 was easily prepared from 4-chloro-2-(trifluoromethyl)quinoline $\mathbf{5}$ and $N$-tosylhydrazone 3a. We next focused our attention on isoCoQuine $\mathbf{2} \mathbf{m}$ possessing a tri-substituted ethylene bond and having structural analogies with a bioactive analogues of isoCA-4 previously prepared in our group.[12] This quinoline $\mathbf{2 m}$ was synthetized in two steps from the ozonolysis of isoCoQuine 2a and provided the expected 1,1-diarylketone 6. The latter compound was then subjected to a Wittig-Horner olefination to provide give $\mathbf{2 m}$ (49\%).[28] In view of structure-activity relationships and to evaluate the importance of the nitrogen atom of such heterocycles and particularly isoCoQuines, the naphthyl derivative $\mathbf{2 n}$ was also prepared from the Pd-coupling reaction between 3a and 1-chloro-3-methylnaphtalene in a sealed tube at $100{ }^{\circ} \mathrm{C}$ $(79 \%)$.

\subsection{Biological results.}

In vitro cytotoxicity of the synthesized compounds 2 was investigated against U87 human glioblastoma cell line. A fluorimetry-based assay was used for determination of the drug concentration required to inhibit cell growth by $50 \%$ after incubation in the culture medium for $72 \mathrm{~h}$. IsoCA-4 and isoCoQ 1 were included as reference compounds for comparisons. To investigate whether these derivatives were exerting their activity by interactions with microtubules, all drugs 2 were also evaluated for their anti-tubulin activities. The cytotoxicity results of novel derivatives 2 and 1,1arylheteroarylketone $\mathbf{6}$ are presented in Table 1.

Table 1 Cytotoxicity against U87 cells ${ }^{a}$ and ITP of compounds $\mathbf{2 a - i ,} 2 \mathbf{k}-\mathbf{n}$ and ketone $\mathbf{6}$

\begin{tabular}{|c|c|c|c|c|c|c|c|c|}
\hline Compound & $\mathbf{2 a}$ & $2 \mathbf{b}$ & $2 c$ & $2 d$ & $2 e$ & $2 f$ & $2 \mathrm{~g}$ & $2 \mathrm{~h}$ \\
\hline Cytotoxicity $\mathrm{IC}_{50}{ }^{b}[\mathrm{nM}]$ & $21 \pm 0.1$ & $1.5 \pm 0.05$ & $4 \pm 0.07$ & $300 \pm 1$ & $690 \pm 10$ & $1 \pm 0.1$ & $240 \pm 10$ & $75 \pm 1$ \\
\hline $\mathrm{ITP} \mathrm{IC}_{50}{ }^{c}[\mu \mathrm{M}]$ & $1.1 \pm 0.2$ & $3.9 \pm 0.9$ & $2.2 \pm 0.4$ & $e$ & $f$ & $1.1 \pm 0.2$ & $23.8 \pm 3.3$ & $g$ \\
\hline Compound & $2 \mathbf{i}$ & $2 \mathbf{k}$ & 21 & $2 \mathrm{~m}$ & $2 n$ & 6 & isoCA-4 & isoCoQ 1 \\
\hline Cytotoxicity $\mathrm{IC}_{50} b[\mathrm{nM}]$ & $2.3 \pm 0.1$ & $390 \pm 10$ & $21.7 \pm 0$ & $0.25 \pm 0.01$ & $140 \pm 1$ & $25 \pm 0.8$ & $7.8 \pm 0.1$ & $6.1 \pm 0.5$ \\
\hline ITP $\mathrm{IC}_{50}^{c}[\mu \mathrm{M}]$ & $3.9 \pm 0.6$ & $14.3 \pm 1.4$ & - & $1.9 \pm 0.3$ & $17.1 \pm 2.3$ & $7.2 \pm 1.2$ & $2.0 \pm 0.1$ & $0.6 \pm 0.1$ \\
\hline
\end{tabular}

${ }^{a}$ U87 Human glioblastoma. ${ }^{b} \mathrm{IC}_{50}$ is the concentration of compound needed to reduce cell growth by $50 \%$ following $72 \mathrm{~h}$ cell treatment with the tested drug (average of three experiments). ${ }^{c} \mathrm{IC}_{50}$ is the concentration of compound required to inhibit $50 \%$ of the rate of microtubule assembly (average of three experiments). ${ }^{d}$ Not active. ${ }^{e} 53 \%$ of inhibition at a concentration of $100 \mu \mathrm{M} .{ }^{f} 24 \%$ of inhibition at a concentration of $100 \mu \mathrm{M} .{ }^{g} 29$ $\%$ of inhibition at a concentration of $100 \mu \mathrm{M}$.

IsoCoQuine 2a, having a 4-methoxy substituent on B-ring exhibited a potent antiproliferative activity against U87 cells with an $\mathrm{IC}_{50}$ value of $21 \mathrm{nM}$. For comparison, its 2-methylquinazolinic analogue [23] displayed a slightly lowest cytotoxicity $\left(\mathrm{IC}_{50}=40 \mathrm{nM}\right)$, strengthening our ideas that nitrogen-containing heterocycles, as quinolines, are good surrogates for the 3,4,5-trimethoxyphenyl ring of isoCA-4. As it was previously observed in CA-4 and isoCA-4 series, introducing small substituents on the meta-position of the B-ring of $\mathbf{2 a}$ as hydroxyle function or a fluorine atom led to more potent derivatives having $\mathrm{IC}_{50}$ values inferiors to $5 \mathrm{nM}$. It should be noted that phenol derivative $\mathbf{2 b}\left(\mathrm{IC}_{50}=1.5\right.$ $\mathrm{nM})$ is slightly more cytotoxic against U87 cells than isoCA-4 $\left(\mathrm{IC}_{50}=7.8 \mathrm{nM}\right)$ and than its quinazolinic analogue, isoCoQ $1\left(\mathrm{IC}_{50}=6.1 \mathrm{nM}\right)$. The $\mathrm{IC}_{50}$ values obtained for isoquinoline $\mathbf{2 d}\left(\mathrm{IC}_{50}=300 \mathrm{nM}\right)$ and for quinoxaline $\mathbf{2 e}\left(\mathrm{IC}_{50}=\right.$ $690 \mathrm{nM}$ ) showed that these nitrogen containing heterocycles were less suitable for an improved cytotoxicity than their counterpart quinoline as $\mathbf{2 a}$ which was similarly substituted $\left(\mathrm{IC}_{50}=21 \mathrm{nM}\right)$. Next, we have evaluated the importance of 
various substituents on the C-2 of quinolines $\mathbf{2}$ by replacements of the methyl substituent. Interestingly, quinolines $\mathbf{2 f}$ and $2 \mathbf{i}$ having a $\mathrm{CN}$ or a $\mathrm{CO}_{2} \mathrm{Me}$ group on the $\mathrm{C}-2$ position respectively, also displayed a good level of cytotoxicity with $\mathrm{IC}_{50}$ values against U87 cells equal to $1 \mathrm{nM}$ and $2.3 \mathrm{nM}$, respectively. However, introduction of other polar substituents as a $\mathrm{CONH}_{2}$ present in $\left(\mathbf{2 g} ; \mathrm{IC}_{50}=240 \mathrm{nM}\right), \mathrm{COOH}\left(\mathbf{2 h} ; \mathrm{IC}_{50}=75 \mathrm{nM}\right)$ or $\mathrm{CH}_{2} \mathrm{OH}\left(\mathbf{2} \mathbf{k} ; \mathrm{IC}_{50}=390 \mathrm{nM}\right)$ at the C-2 position resulted in an important decrease in the mean of $\mathrm{IC}_{50}$ values. Quinoline $2 \mathbf{2}$ having on $\mathrm{C}-2$ a $\mathrm{CF}_{3}$ lipophilic substituent displayed an interesting $\mathrm{IC}_{50}$ value of $21.7 \mathrm{nM}$. As expected, and as observed in the isoCA-4 series, the introduction of a $\mathrm{CN}$-function on the double bond of $\mathbf{2 a}$ gave $\mathbf{2 m}$ (as a mixture of inseparable isomers) which displayed an excellent level of cytotoxicity $\left(\mathbf{2} \mathbf{m}, \mathrm{IC}_{50}=0.25 \mathrm{nM}\right)$. This compound may constitutes a valuable payload for antibody drug conjugates (ADCs). Finally, the high $\mathrm{IC}_{50}$ value of naphthalene $2 \mathbf{n}(140 \mathrm{nM})$ clearly demonstrated the importance of the nitrogen atom (N-1) in quinolines of type $\mathbf{2}$ for the design of novel chemotherapeutic drugs. To investigate whether these derivatives were exerting their activities by interactions with microtubules, compounds 2 were next evaluated for their antitubulin activities (Table 1). The results indicated clearly that tubulin is the intracellular target of nitrogen-containing heterocycles 2 because all of them were potent inhibitors of tubulin assembly with micromolar $\mathrm{IC}_{50}$ values. It is important to note that quinoline $\mathbf{2 a}$ exhibited a $\mathrm{IC}_{50}$ value against tubulin $(1.1 \mu \mathrm{M})$ substantially weaker than those of its analogous isoquinoline $\mathbf{2 d}$, quinoxaline $2 \mathbf{e}$ and naphthalene $\mathbf{2 n}$ reinforcing our ideas that a quinoline ring is important for improved anti-cancer activities in connection with a significant involvement of $\beta$-tubulin. As expected, we were pleased to observe that quinoline $\mathbf{2} \mathbf{m}$ having a tri-substituted ethylene bond was as active as $i s o \mathrm{CA}-4$ against tubulin with an $\mathrm{IC}_{50}$ value of $1.9 \mu \mathrm{M}$. As observed with these preliminary cytotoxicity results, the replacement of the Me-substituent on $\mathrm{C}-2$ (2a) by a $\mathrm{CN}(\mathbf{2 f})$ or a $\mathrm{CO}_{2} \mathrm{Me}(\mathbf{2 i})$ group is authorized and led to an equipotent anti-

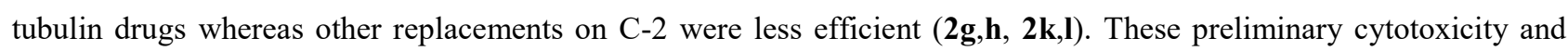
inhibition of tubulin assembly results showed that quinolines $\mathbf{2 a - c}, \mathbf{2 f}, \mathbf{2 i}$ and $\mathbf{2} \mathbf{m}$ are promising drugs in this novel series of heterocyclic derivatives.[29] In this context, we next investigated their effects on the proliferation of four other tumor cell lines: chronic myeloid leukaemia in blast crisis (K562), doxorubicin-resistant K562 (K562R), human lung adenocarcinoma epithelial cells (A549) and human colon carcinoma (HCT116).

Table 2. Cytotoxicity against human cancer cell lines, U87, K562, K562R, A549 and HCT116.

\begin{tabular}{cccccc}
\hline \multicolumn{5}{c}{ Cytotoxicity $\left(\mathrm{IC}_{50} \mathrm{nM}\right)$} \\
\hline Compounds & $\mathrm{U} 87$ & $\mathrm{~K} 562^{b}$ & $\mathrm{~K} 562 \mathrm{R}^{c}$ & $\mathrm{~A}^{c} 49^{d}$ & $\mathrm{HCT}_{116^{e}}$ \\
$\mathbf{2 a}$ & $21 \pm 0.1$ & $17 \pm 0.5$ & $0.7 \pm 0.03$ & $18.5 \pm 0.2$ & $3 \pm 0.2$ \\
$\mathbf{2 b}$ & $\mathbf{1 . 5} \pm \mathbf{0 . 0 5}$ & $\mathbf{1 . 8} \pm \mathbf{4}$ & $\mathbf{2 . 4} \pm \mathbf{2}$ & $\mathbf{0 . 4} \pm \mathbf{0 . 0 4}$ & $\mathbf{0 . 9} \pm \mathbf{0 . 1}$ \\
$\mathbf{2 c}$ & $4 \pm 0.07$ & $5.0 \pm 0.7$ & $2.4 \pm 0.3$ & $9.5 \pm 0.2$ & $9.6 \pm 0.5$ \\
$\mathbf{2 f}$ & $1 \pm 0.1$ & $9 \pm 2$ & $0.9 \pm 0.1$ & $50 \pm 0.8$ & $1.6 \pm 0.1$ \\
$\mathbf{2 i}$ & $2.3 \pm 0.1$ & $88 \pm 2$ & $18 \pm 0.5$ & $\mathrm{nd}^{g}$ & $160 \pm 8$ \\
$\mathbf{2 m}$ & $0.25 \pm 0.01$ & $17 \pm 0.3$ & $6.6 \pm 0.2$ & $79 \pm 2$ & $13.2 \pm 0.8$ \\
$\mathbf{6}$ & $25 \pm 0.8$ & $139 \pm 4$ & $52 \pm 1$ & $\mathrm{nd}^{g}$ & $130 \pm 10$ \\
$\mathbf{I s o C A - 4}$ & $7.8 \pm 0.06$ & $0.8 \pm 0.1$ & $1.1 \pm 0.2$ & $8.2 \pm 0.7$ & $2.0 \pm 0.1$ \\
\hline
\end{tabular}

${ }^{a} \mathrm{IC}_{50}$ is the concentration of compound needed to reduce cell growth by $50 \%$ following $72 \mathrm{~h}$ cell treatment with the tested drug (average of three experiments). ${ }^{b} \mathrm{~K} 562$, chronic myeloid leukemia cells in blast crisis. ${ }^{c} \mathrm{~K} 562 \mathrm{R}$, doxorubicin-resistant K562 cells, ${ }^{d}$ A549, human lung epithelial cells. ${ }^{e}$ HCT116 human colon carcinoma. ${ }^{f} \mathrm{The}^{\mathrm{IC}} \mathrm{C}_{50}$ values of $i s o \mathrm{CA}-4$ was determined in this study. ${ }^{g}$ not determined.

The results depicted in Table 2 revealed that all selected isoCoQuines 2 were also strongly cytotoxic with nanomolar $\mathrm{IC}_{50}$ values. Quinoline $2 \mathbf{b}\left(0.4 \mathrm{nM}<\mathrm{IC}_{50}<2.4 \mathrm{nM}\right)$ and in a lesser extent quinoline $2 \mathrm{c}\left(2.4 \mathrm{nM}<\mathrm{IC}_{50}<9.6 \mathrm{nM}\right)$ displayed a constant high level of cytotoxicity against all tested cancer cell lines. On the contrary, quinoline $\mathbf{2 f}$ having a $\mathrm{CN}$-group on the $\mathrm{C}-2$ position which was a very cytotoxic at a nanomolar level against U87 and K562R displayed a 
lower level of cytotoxicity against the human lung epithelial cells $\left(\mathrm{IC}_{50}=50 \mathrm{nM}\right)$. One note that quinoline $\mathbf{2 m}$ which was found to be the more cytotoxic agent against U87 cells with a picomolar $\mathrm{IC}_{50}$ value $(250 \mathrm{pM})$ was dramatically 300-fold less cytotoxic against A549 cell lines $\left(\mathrm{IC}_{50}=79 \mathrm{nM}\right)$. IsoCoQuine $\mathbf{2 b}$ which displayed against the five cancer cell lines U87, K562, K562R, A549 and HCT116 a high and homogeneous cytotoxicity level $\left(0.4 \mathrm{nM}<\mathrm{IC}_{50}<2.4 \mathrm{nM}\right)$ was next tested in dose-response experiments on A549 cell cycle distribution. A549 cells were treating for 24 h with increasing nanomolar concentrations $(0.5,1,5$ and $10 \mathrm{nM})$ and DMSO was used as control. As seen in Fig. 2, isoCoQuine $\mathbf{2 b}$, at a concentration of $10 \mathrm{nM}$, has arrested the entire population of A549 cells in the G2/M phase of the cellular cycle as it was previously observed for antimitotic derivatives in the isoCA-4 series.[11]

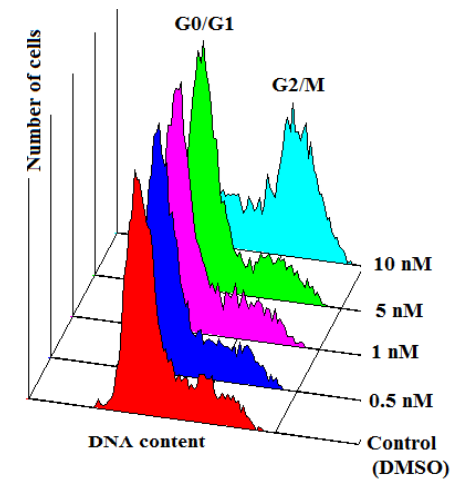

Fig. 2. Effects of $\mathbf{2 b}$ on cell cycle distribution in A549 cells determined by flow cytometry analysis. DNA content was assessed via propidium iodide staining.
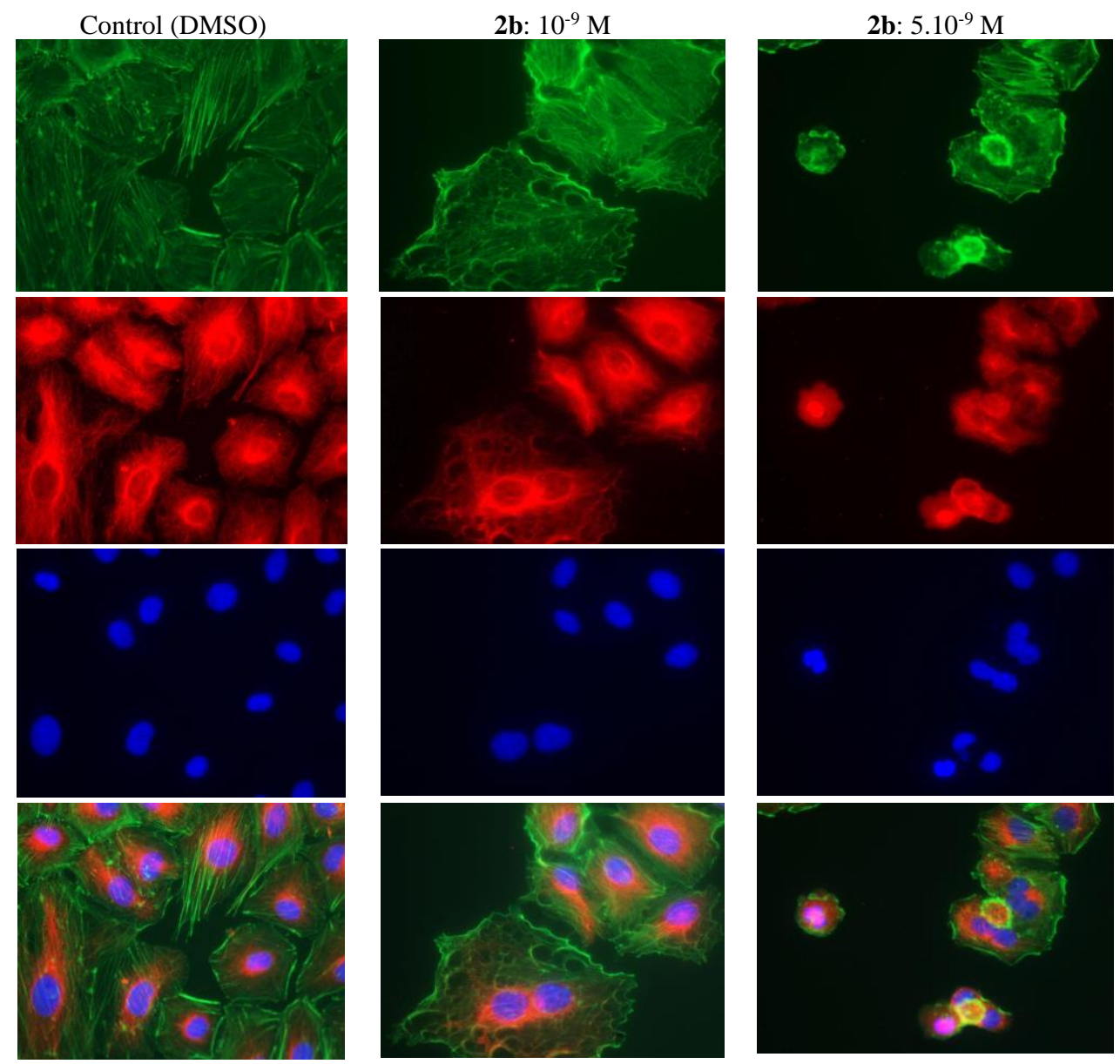

A549 cells

Fig. 3. Effect of $\mathbf{2 b}$ on microtubule network organization. A549 cells were treated with $\mathbf{2 b}$ for $24 \mathrm{~h}$. After incubation, the cells were fixed and stained with monoclonal $\beta$-tubulin antibody (red), cell nuclei were stained with DAPI (blue) and Alexa Fluor ${ }^{\circledR} 488$ Phalloidin (green) was used to visualize actin skeleton. 
To support that isoCoQuines $\mathbf{2}$ and particularly isoCoQuine $\mathbf{2 b}$ inhibit polymerization of $\beta$-tubulin, we evaluated its ability to alter the microtubule network of A549 cells using cell-base immunofluorescence staining assays (Fig. 3).We observed that, after $24 \mathrm{~h}$ of treatment, $\mathbf{2 b}$ caused fragmentation of the microtubule network and disrupted mitotic spindle formation at a low concentration of $1 \mathrm{nM}$. A549 cells showed a dose-dependent disruption and loss of microtubules and, at a concentration of $5 \mathrm{nM}$, we observed a severe destruction of the microtubule system (red), a disorganization of actin network (green) and multinucleated cells (blue).

\subsection{Docking study.}

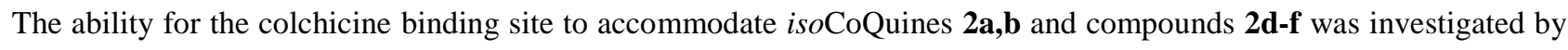
molecular docking against five conformations of tubulin available [30] in the PDB database. Results for three of these compounds which displayed a high level of cytotoxicity (2a,b and $\mathbf{2 f}$ ) are shown in Figure 4.

Where A-ring of isoCA-4 possessed a 4-methoxy group establishing a hydrogen bond with Cys241 residue belonging to the $\beta$-subunit of tubulin, isoCoQuines of type 2 exhibit their nitrogen atoms capable of playing the same hydrogen bond acceptor role. In the case of isoCoQuine $\mathbf{2 b}$, an extra hydrogen bond is formed by the $\mathrm{OH}$ function with residue Thro179. In low bio-active compounds isoquinoline $\mathbf{2 d}$ and quinoxaline $\mathbf{2 e}$, though, the position of the aromatic nitrogen(s) is inadequate for interacting with Cys $\beta 241$ (data not shown). The replacement of the Me-substituent on C-2 of the quinoline ring in $\mathbf{2 a}$ by a $\mathrm{CN}$ function (isoCoQuine $\mathbf{2 f}$ ) led to equivalent drugs (similar cytotoxicities and IPT IC 50 values) which adopt a similar positioning in the colchicine binding site and establish a hydrogen bond between $\mathrm{N}-1$ and Cys241.

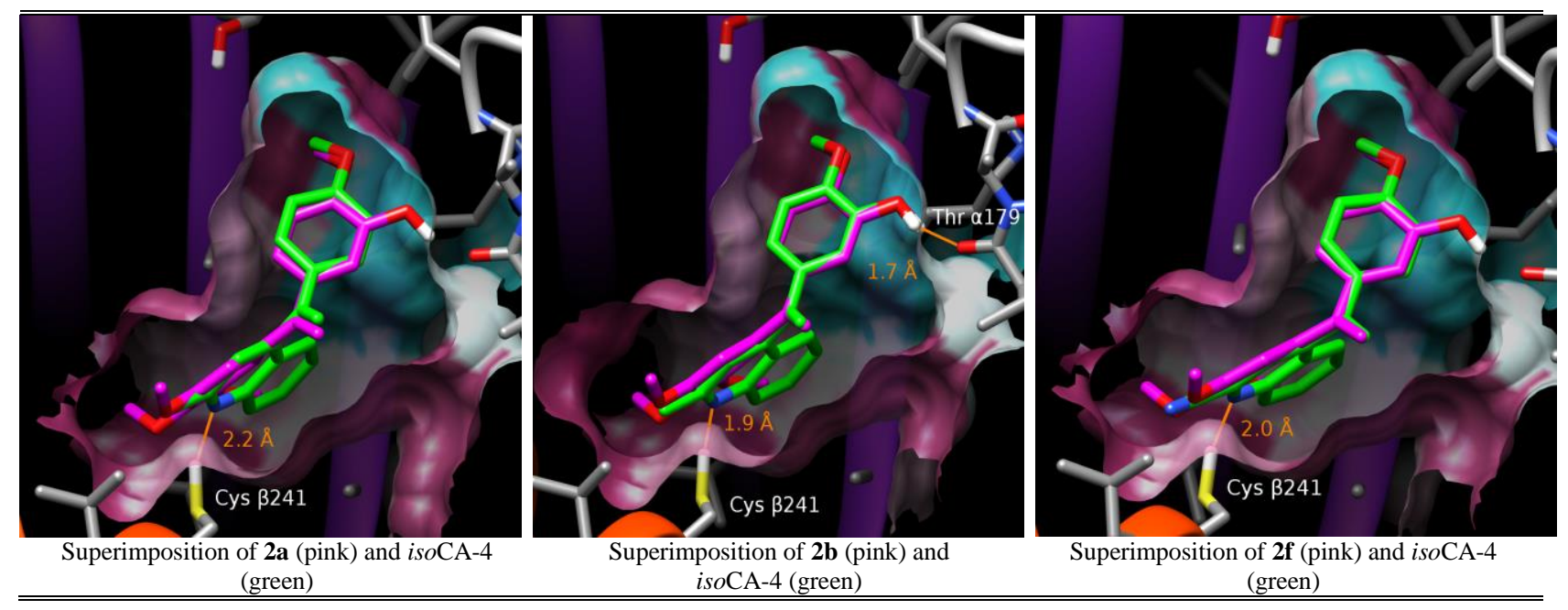

Fig. 4. Calculated binding mode for derivatives $\mathbf{2 a}, \mathbf{2 b}$ and $\mathbf{2 f}$ in the colchicine binding site of tubulin and superimposition of the latter with that of isoCA-4. The color of solvent-accessible surface indicates its polarity (cyan means polar and purple means nonpolar). Orange lines represent hydrogen bonds.

\section{Conclusion}

In this work, we have designed and synthesized a series of isoCA-4 derivatives having a quinoline A-ring and found that these compounds show good growth inhibition activities against a range of human cancer cells. We demonstrated that replacing a quinazoline-A-ring by a quinoline resulted in more potent derivatives. The more interesting isoCoQuine $\mathbf{2 b}$, having the greatest resemblance to isoCA-4 and quinazoline $\mathbf{1}$ displayed a nano- and subnanomolar level of cytotoxicity against five cancer cell lines and inhibited tubulin polymerization with micromolar $\mathrm{IC}_{50}$ values. These results demonstrated that incorporation of a quinoline as A-ring in $\mathbf{2 b}$ in place of a quinazoline in $\mathbf{1}$ improved anticancer activity, characterized by a high level of cytotoxicity. After $24 \mathrm{~h}$ of treatment with isoCoQuin $2 \mathbf{b}$, A549 cells were arrested in the G2/M phase at a concentration of $10 \mathrm{nM}$ as it was observed with other isoCA-4 derivatives.[31, 32] Docking studies show that isoCoQuin $\mathbf{2 b}$ adopts a similar orientation to that of isoCA-4 when bound to $\beta$-tubulin. We 
also observe that the nitrogen atom N-1 of the quinoline A-ring establish an important hydrogen bond with Cys241 residue belonging to the $\beta$-subunit of tubulin as it was previously showed with the 4-MeO substituent of the A-ring in the CA-4 and isoCA-4 series.

\section{Experimental}

\subsection{General considerations}

The compounds were all identified by usual physical methods, i.e. ${ }^{1} \mathrm{H}$ NMR, ${ }^{13} \mathrm{C}$ NMR, ${ }^{19} \mathrm{~F}$ NMR, IR, HRMS. ${ }^{1} \mathrm{H},{ }^{13} \mathrm{C}$ and ${ }^{19} \mathrm{~F}$ NMR spectra were measured in $\mathrm{CDCl}_{3}$ with a Bruker AMX $200\left({ }^{1} \mathrm{H},{ }^{13} \mathrm{C}\right.$ and $\left.{ }^{19} \mathrm{~F}\right)$ or with a Bruker Avance 300 $\left({ }^{1} \mathrm{H}\right.$ and $\left.{ }^{13} \mathrm{C}\right) .{ }^{1} \mathrm{H}$ chemical shifts are reported in ppm from an internal standard TMS or of residual chloroform (7.27 ppm). The following abbreviations are used: $\mathrm{m}$ (multiplet), s (singlet), $\mathrm{d}$ (doublet), brs (broad singlet), $\mathrm{t}$ (triplet), ${ }^{13} \mathrm{C}$ chemical shifts are reported in ppm from the central peak of $\mathrm{CDCl}_{3}$ (77.14). IR spectra were measured on a Bruker Vector 22 spectrophotometer (neat, $\mathrm{cm}^{-1}$ ). Mass spectra were obtained with a LCT Micromass spectrometer. Analytical TLC was performed on Merck pre-coated silica gel 60F plates. Merck silica gel 60 (230-400 mesh) was used for column chromatography.

\subsubsection{Synthesis of 4-chloroquinoline-2-carbonitrile 4 (93\%)}

To a solution of 2,4-dichloroquinoline (444 mg, $2.24 \mathrm{mmol})$ in DMF (5 mL) was added zinc cyanide (117 mg, 1.14 mmol) and $\mathrm{Pd}\left(\mathrm{PPh}_{3}\right)_{4}(259 \mathrm{mg}, 0.22 \mathrm{mmol})$. The reaction mixture was stirred at $120{ }^{\circ} \mathrm{C}$ for $1 \mathrm{~h}$. $\mathrm{A}$ saturated $\mathrm{NH}$ solution $(20 \mathrm{~mL})$ was added and the mixture was extracted with ethyl acetate $(3 \times 5 \mathrm{~mL})$. The organic layer was washed with a $\mathrm{NaCl}$ solution $(5 \mathrm{~mL})$ and dried over sodium sulfate, filtered and evaporated. The product was further purified by chromatography on silica gel eluting with cyclohexane/ethyl acetate (95:5) to give 4 (392 $\mathrm{mg}, 2.085 \mathrm{mmol}, 93 \%)$ as a white solid.

White solid. $\mathrm{F}=108.9-109.3{ }^{\circ} \mathrm{C} .{ }^{1} \mathrm{H}$ NMR $\left(300 \mathrm{MHz}, \mathrm{CDCl}_{3}\right) \delta 8.12(\mathrm{~d}, J=8.4 \mathrm{~Hz}, 1 \mathrm{H}), 8.06(\mathrm{~d}, J=8.4 \mathrm{~Hz}, 1 \mathrm{H}), 7.81$ $(\mathrm{t}, J=7.6 \mathrm{~Hz}, 1 \mathrm{H}), 7.70(\mathrm{t}, J=7.6 \mathrm{~Hz}, 1 \mathrm{H}), 7.61(\mathrm{~s}, 1 \mathrm{H}) .{ }^{13} \mathrm{C} \mathrm{NMR}\left(75 \mathrm{MHz}, \mathrm{CDCl}_{3}\right) \delta 148.9,144.3,133.4,132.2$, 130.7 (2C), 127.3, 124.4, 123.4, 116.8. IR neat $v_{\max /} \mathrm{cm}^{-1}: 3093,2344,2240,1570,1491,1403,1292,1024$. HRMS calcd for $\mathrm{C}_{10} \mathrm{H}_{6} \mathrm{~N}_{2} \mathrm{Cl}[\mathrm{M}+\mathrm{H}]^{+} 189.0220$, obsd. 189.0217 .

\subsubsection{Synthesis of isoCoQuines 2}

General procedure for the synthesis of compounds $\mathbf{2 a}, \mathbf{2 b}, \mathbf{2 c}, \mathbf{2 d}, \mathbf{2 \mathbf { f } , 2 \mathbf { l }}$

In a sealed tube and under an argon atmosphere were added successively, $\mathrm{ArCl}$ (0.5 mmol), hydrazone 3a or 3c (for $\mathbf{2 c}$ ) $(0.75 \mathrm{mmol}) \mathrm{PdCl}_{2}\left(\mathrm{CH}_{3} \mathrm{CN}\right)_{2}(10 \mathrm{~mol} \%)$, dppf $(20 \mathrm{~mol} \%)$ in dry dioxane $(4 \mathrm{~mL})$ and the mixture was stirred for $5 \mathrm{~min}$. at rt. Then dry $\mathrm{LiO} t \mathrm{Bu}(2.2 \mathrm{mmol})$ ( 1.8 for $\mathbf{2 f}$ ) was added and the mixture was stirred at $100^{\circ} \mathrm{C}$ for $3 \mathrm{~h}$. The resulting suspension was cooled to room temperature, filtered through a pad of Celite eluting with ethyl acetate and the inorganic salts were removed. The filtrate was concentrated and the crude was purified by silica gel column chromatography.

\subsubsection{4-(1-(4-Methoxyphenyl)vinyl)-2-methylquinoline $\mathbf{2 a}(65 \%)$}

Beige solid, $\mathrm{F}=94.5-95.2{ }^{\circ} \mathrm{C} .{ }^{1} \mathrm{H} \mathrm{NMR}\left(300 \mathrm{MHz}, \mathrm{CDCl}_{3}\right) \delta 8.08(\mathrm{~d}, J=9.1 \mathrm{~Hz}, 1 \mathrm{H}), 7.75(\mathrm{~d}, J=9.1 \mathrm{~Hz}, 1 \mathrm{H}), 7.66(\mathrm{t}$, $J=8.4 \mathrm{~Hz}, 1 \mathrm{H}), 7.36(\mathrm{t}, J=8.4 \mathrm{~Hz}, 1 \mathrm{H}), 7.24(\mathrm{~d}, J=8.9 \mathrm{~Hz}, 2 \mathrm{H}), 6.84(\mathrm{~d}, J=8.9 \mathrm{~Hz}, 2 \mathrm{H}), 5.94(\mathrm{~s}, 1 \mathrm{H}), 5.32(\mathrm{~s}, 1 \mathrm{H})$, $3.81(\mathrm{~s}, 3 \mathrm{H}), 2.80(\mathrm{~s}, 3 \mathrm{H}) .{ }^{13} \mathrm{C} \mathrm{NMR}\left(75 \mathrm{MHz}, \mathrm{CDCl}_{3}\right) \delta 159.7,158.9,148.9,148.3,145.6,132.5,129.4,129.0(2)$, 127.9, 126.1, 125.7, 125.5, 122.5, 115.1, 114.0 (2), 55.4, 25.4. IR (neat) $v_{\max } / \mathrm{cm}^{-1}: 2961,2929,1651,1591,1510,1440$, 1351. HRMS calcd for $\mathrm{C}_{19} \mathrm{H}_{18} \mathrm{NO}[\mathrm{M}+\mathrm{H}]^{+} 276.1388$, obsd. 276.1388. 
4.2.2.2. 2-Methoxy-5-(1-(2-methylquinolin-4-yl)vinyl)phenol $\mathbf{2 b}$ (45\% for the coupling and the cleavage of the O-Si bond)

Beige solid, $\mathrm{F}=107.5-108.3{ }^{\circ} \mathrm{C} .{ }^{1} \mathrm{H}$ NMR $\left(300 \mathrm{MHz}, \mathrm{CDCl}_{3}\right) \delta 9.00(\mathrm{~s}, 1 \mathrm{H}), 7.89(\mathrm{~d}, J=8.2 \mathrm{~Hz}, 1 \mathrm{H}), 7.71(\mathrm{~d}, J=8.2$ $\mathrm{Hz}, 1 \mathrm{H}), 7.52(\mathrm{t}, J=8.1 \mathrm{~Hz}, 1 \mathrm{H}), 7.31(\mathrm{t}, J=8.1 \mathrm{~Hz}, 1 \mathrm{H}), 7.10(\mathrm{~s}, 1 \mathrm{H}), 7.03(\mathrm{~d}, J=8.4 \mathrm{~Hz}, 1 \mathrm{H}), 6.88(\mathrm{~d}, J=8.4 \mathrm{~Hz}$, $1 \mathrm{H}), 6.72(\mathrm{~s}, 1 \mathrm{H}), 5.95(\mathrm{~s}, 1 \mathrm{H}), 5.24(\mathrm{~s}, 1 \mathrm{H}), 3.93(\mathrm{~s}, 3 \mathrm{H}), 2.52(\mathrm{~s}, 3 \mathrm{H}) .{ }^{13} \mathrm{C} \mathrm{NMR}\left(75 \mathrm{MHz}, \mathrm{CDCl}_{3}\right) \delta 158.4,149.7$, 147.7, 147.0, 146.5, 145.3, 132.6, 129.6, 127.7, 126.2, 125.8, 125.5, 122.5, 117.2, 114.8, 114.0, 111.4, 56.1, 24.3. IR (neat) $v_{\max } / \mathrm{cm}^{-1}: 3162,2840,2363,1594,1560,1515,1461,1350$. HRMS calcd for $\mathrm{C}_{19} \mathrm{H}_{18} \mathrm{NO}_{2}[\mathrm{M}+\mathrm{H}]^{+} 292.1338$, obsd. 292.1330.

\subsubsection{4-(1-(3-Fluoro-4-methoxyphenyl)vinyl)-2-methylquinoline $2 \mathbf{c}(37 \%)$}

Pale yellow oil. ${ }^{1} \mathrm{H}$ NMR $\left(300 \mathrm{MHz}, \mathrm{CDCl}_{3}\right) \delta 8.03(\mathrm{~d}, J=8.4 \mathrm{~Hz}, 1 \mathrm{H}), 7.64(\mathrm{~d}, J=8.4 \mathrm{~Hz}, 1 \mathrm{H}), 7.56(\mathrm{t}, J=7.3 \mathrm{~Hz}$, $1 \mathrm{H}), 7.26(\mathrm{t}, J=7.3 \mathrm{~Hz}, 1 \mathrm{H}), 7.16(\mathrm{~s}, 1 \mathrm{H}), 7.06(\mathrm{~d}, J=12.5 \mathrm{~Hz}, 1 \mathrm{H}), 6.84(\mathrm{~d}, J=8.5 \mathrm{~Hz}, 1 \mathrm{H}), 6.72(\mathrm{t}, J=8.5 \mathrm{~Hz}, 1 \mathrm{H})$, $5.84(\mathrm{~s}, 1 \mathrm{H}), 5.28(\mathrm{~s}, 1 \mathrm{H}), 3.75(\mathrm{~s}, 3 \mathrm{H}), 2.71(\mathrm{~s}, 3 \mathrm{H}) \cdot{ }^{13} \mathrm{C} \mathrm{NMR}\left(75 \mathrm{MHz}, \mathrm{CDCl}_{3}\right) \delta 158.8,153.0(\mathrm{~d}, J=244.5 \mathrm{~Hz})$, 148.2, 148.0, 147.6 (d, $J=10.5 \mathrm{~Hz}), 144.8,132.9$ (d, $J=6.0 \mathrm{~Hz}), 129.3,129.0,125.8,125.7,125.2,122.7(\mathrm{~d}, J=3.0$ $\mathrm{Hz}), 122.4,116.1,114.0(\mathrm{~d}, J=19.5 \mathrm{~Hz}), 113.1,56.1,25.3 .{ }^{19} \mathrm{~F}$ NMR $\left(188 \mathrm{MHz}, \mathrm{CDCl}_{3}\right) \delta-135.2 . \mathrm{IR}(\mathrm{neat}) v_{\max } / \mathrm{cm}^{-1}$ : 2841, 1616, 1594, 1516, 1463, 1433. HRMS calcd for $\mathrm{C}_{19} \mathrm{H}_{17} \mathrm{FNO}[\mathrm{M}+\mathrm{H}]^{+}$294.1294, obsd. 294.1289.

\subsubsection{1-(1-(4-Methoxyphenyl)vinyl)-3-methylisoquinoline $2 \mathbf{d}$ (41\%)}

White solid, $\mathrm{F}=65.7-66.3{ }^{\circ} \mathrm{C} .{ }^{1} \mathrm{H}$ NMR $\left(300 \mathrm{MHz} \mathrm{CDCl}_{3}\right) \delta 7.92(\mathrm{~d}, J=8.2 \mathrm{~Hz}, 1 \mathrm{H}), 7.75(\mathrm{~d}, J=8.2 \mathrm{~Hz}, 1 \mathrm{H}), 7.60(\mathrm{t}$, $J=8.2 \mathrm{~Hz}, 1 \mathrm{H}), 7.50(\mathrm{~s}, 1 \mathrm{H}), 7.37(\mathrm{t}, J=8.2 \mathrm{~Hz}, 1 \mathrm{H}), 7.26(\mathrm{~d}, J=8.7 \mathrm{~Hz}, 2 \mathrm{H}), 6.81(\mathrm{~d}, J=8.7 \mathrm{~Hz}, 2 \mathrm{H}), 6.04(\mathrm{~s}, 1 \mathrm{H})$, $5.41(\mathrm{~s}, 1 \mathrm{H}), 3.79$ (s, 3H), 2.75 (s, 3H). ${ }^{13} \mathrm{C} \mathrm{NMR}\left(75 \mathrm{MHz}, \mathrm{CDCl}_{3}\right) \delta 161.0,159.5,151.0,146.7,137.3,132.6,130.1$, 127.9 (2), 127.6, 126.3, 126.2, 125.5, 118.3, 115.5, 113.8 (2), 55.3, 24.6. IR (neat) $v_{\max } / \mathrm{cm}^{-1}: 2955,2835,1621,1606$, 1510, 1464, 1252. HRMS calcd for $\mathrm{C}_{19} \mathrm{H}_{18} \mathrm{NO}[\mathrm{M}+\mathrm{H}]^{+} 276.1388$, obsd. 276.1385 .

\subsubsection{4-(1-(4-Methoxyphenyl)vinyl)quinoline-2-carbonitrile $\mathbf{2 f}(62 \%)$}

White solid, $\mathrm{F}=112.4-113.2{ }^{\circ} \mathrm{C} .{ }^{1} \mathrm{H}$ NMR $\left(300 \mathrm{MHz}, \mathrm{CDCl}_{3}\right) \delta 8.19(\mathrm{~d}, J=8.5 \mathrm{~Hz}, 1 \mathrm{H}), 7.89-7.72(\mathrm{~m}, 2 \mathrm{H}), 7.63(\mathrm{~s}$, $1 \mathrm{H}), 7.54(\mathrm{t}, J=8.5 \mathrm{~Hz}, 1 \mathrm{H}), 7.16(\mathrm{~d}, J=8.9 \mathrm{~Hz}, 1 \mathrm{H}), 6.83(\mathrm{~d}, J=8.9 \mathrm{~Hz}, 2 \mathrm{H}), 5.99(\mathrm{~s}, 1 \mathrm{H}), 5.34(\mathrm{~s}, 1 \mathrm{H}), 3.79(\mathrm{~s}, 3 \mathrm{H})$. ${ }^{13} \mathrm{C}$ NMR $\left(75 \mathrm{MHz}, \mathrm{CDCl}_{3}\right) \delta: 159.9,150.8,148.5,144.1,133.4,131.6,131.0,130.2,129.3,127.8$ (2), $126.3,123.7$, 117.5, 116.6 (2), 114.1 (2), 55.3. IR (neat) $v_{\max } / \mathrm{cm}^{-1}: 3062,2838,2236,1605,1576,1441,1218$. HRMS calcd for $\mathrm{C}_{19} \mathrm{H}_{15} \mathrm{~N}_{2} \mathrm{O}[\mathrm{M}+\mathrm{H}]^{+}$287.1184, obsd. 287.1180.

4.2.3. In a sealed tube and under an argon atmosphere were added successively, 2-chloro-3-methylquinoxaline (0.5 mmol), hydrazone 3a $(0.75 \mathrm{mmol}) \mathrm{PdCl}_{2}\left(\mathrm{CH}_{3} \mathrm{CN}\right)_{2}(10 \mathrm{~mol} \%),\left[(\mathrm{tBu})_{2} \mathrm{MePH}\right] \mathrm{BF}_{4}(20 \mathrm{~mol} \%)$ in dry dioxane $(4 \mathrm{~mL})$ and the mixture was stirred for $5 \mathrm{~min}$. at rt. Then dry $\mathrm{LiO} t \mathrm{Bu}(1.8 \mathrm{mmol})$ was added and the mixture was stirred at $100^{\circ} \mathrm{C}$ for $3 \mathrm{~h}$. The resulting suspension was cooled to room temperature, filtered through a pad of Celite eluting with ethyl acetate and the inorganic salts were removed. The filtrate was concentrated and the crude was purified by silica gel column chromatography.

\section{2-(1-(4-Methoxyphenyl)vinyl)-3-methylquinoxaline 2e (57\%)}

Beige solid, $\mathrm{F}=102.2-102.9{ }^{\circ} \mathrm{C} .{ }^{1} \mathrm{H}$ NMR $\left(300 \mathrm{MHz}, \mathrm{CDCl}_{3}\right) \delta 8.14(\mathrm{~d}, J=9.6 \mathrm{~Hz}, 1 \mathrm{H}), 8.05(\mathrm{~d}, J=9.6 \mathrm{~Hz}, 1 \mathrm{H}), 7.84$ $-7.62(\mathrm{~m}, 2 \mathrm{H}), 7.20(\mathrm{~d}, J=8.9 \mathrm{~Hz}, 2 \mathrm{H}), 6.85(\mathrm{~d}, J=8.9 \mathrm{~Hz}, 2 \mathrm{H}), 5.93(\mathrm{~s}, 1 \mathrm{H}), 5.46(\mathrm{~s}, 1 \mathrm{H}), 3.80(\mathrm{~s}, 3 \mathrm{H}), 2.49(\mathrm{~s}, 3 \mathrm{H})$. ${ }^{13} \mathrm{C}$ NMR $\left(75 \mathrm{MHz}, \mathrm{CDCl}_{3}\right) \delta 159.9,155.7,153.5,147.1,141.8,136.6,131.1,129.9,129.5,129.3,128.5,127.8(2)$, 
116.2, 114.2 (2), 55.4, 23.5. IR (neat) $v_{\max } / \mathrm{cm}^{-1}: 2929,2836,1606,1511,1440,1248$. HRMS calcd for $\mathrm{C}_{19} \mathrm{H}_{17} \mathrm{~N}_{2} \mathrm{O}$ $[\mathrm{M}+\mathrm{H}]^{+}$277.1341, obsd. 277.1336.

\subsubsection{4-(1-(4-Methoxyphenyl)vinyl)quinoline-2-carboxamide $\mathbf{2 g}(70 \%)$}

In a sealed tube and under an argon atmosphere were added successively, 4 (1 mmol), hydrazone 3a (1.5 mmol) $\mathrm{PdCl}_{2}\left(\mathrm{CH}_{3} \mathrm{CN}\right)_{2}(10 \mathrm{~mol} \%)$, dppf $(20 \mathrm{~mol} \%)$ in dioxane $(4 \mathrm{~mL})$ and the mixture was stirred for $5 \mathrm{~min}$. at rt. Then $\mathrm{LiO} t \mathrm{Bu}(3.6 \mathrm{mmol})$ was added and the mixture was stirred at $100^{\circ} \mathrm{C}$ for $3 \mathrm{~h}$. The resulting suspension was cooled to room temperature, filtered through a pad of Celite eluting with ethyl acetate and the inorganic salts were removed. The filtrate was concentrated and the crude was purified by silica gel column chromatography.

White solid, $\mathrm{F}=184.1-184.9{ }^{\circ} \mathrm{C} .{ }^{1} \mathrm{H}$ NMR $\left(300 \mathrm{MHz}, \mathrm{CDCl}_{3}\right) \delta 8.25(\mathrm{~s}, 1 \mathrm{H}), 8.13(\mathrm{~d}, J=7.9 \mathrm{~Hz}, 1 \mathrm{H}), 7.83(\mathrm{~d}, J=7.9$ $\mathrm{Hz}, 1 \mathrm{H}), 7.72(\mathrm{t}, J=7.6 \mathrm{~Hz}, 1 \mathrm{H}), 7.47(\mathrm{t}, J=7.6 \mathrm{~Hz}, 1 \mathrm{H}), 7.18(\mathrm{~d}, J=8.8 \mathrm{~Hz}, 2 \mathrm{H}), 6.80(\mathrm{~d}, J=8.8 \mathrm{~Hz}, 2 \mathrm{H}), 5.95(\mathrm{~s}$, 1H), $5.76(\mathrm{~s}, 2 \mathrm{H}), 5.34(\mathrm{~s}, 1 \mathrm{H}), 3.78(\mathrm{~s}, 3 \mathrm{H}) .{ }^{13} \mathrm{C} \mathrm{NMR}\left(75 \mathrm{MHz}, \mathrm{CDCl}_{3}\right) \delta 167.2,159.8,150.5,149.2,147.2,145.3$, $132.5,130.3,130.0,128.4,128.1,128.0$ (2), 126.4, 119.5, 116.1, 114.1 (2), 55.4. IR (neat) $v_{\max } / \mathrm{cm}^{-1}: 2838,2236$, 1675, 1605, 1441, 1218, 1153. HRMS calcd for $\mathrm{C}_{19} \mathrm{H}_{17} \mathrm{~N}_{2} \mathrm{O}_{2}[\mathrm{M}+\mathrm{H}]^{+} 305.1290$, obsd. 305.1283

\subsubsection{4-(1-(4-Methoxyphenyl)vinyl)quinoline-2-carboxylic acid $\mathbf{2 h}(63 \%)$}

In a sealed tube was added $\mathbf{2 g}(100 \mathrm{mg}, 0.33 \mathrm{mmol})$ in a $3 \mathrm{M}$ solution of $\mathrm{NaOH}(8 \mathrm{~mL})$ and the mixture was stirred at $100{ }^{\circ} \mathrm{C}$ for $4.5 \mathrm{~h}$. EtOAc was added to the cooled mixture which was neutralized with $\mathrm{HCl} 1 \mathrm{~N}$ until $\mathrm{pH}=2$. After extraction, organic layers were dried $\left(\mathrm{Na}_{2} \mathrm{SO}_{4}\right)$ and concentrated in vacuo. The crude was purified by preparative HPLC to give $\mathbf{2 h}(63 \mathrm{mg}, 63 \%)$.

Pale yellow solid, $\mathrm{F}=114.2-115.1{ }^{\circ} \mathrm{C} .{ }^{1} \mathrm{H}$ NMR $\left(300 \mathrm{MHz}, \mathrm{CDCl}_{3}\right) \delta 8.22-8.20(\mathrm{~m}, 2 \mathrm{H}), 7.89(\mathrm{~d}, J=8.5 \mathrm{~Hz}, 1 \mathrm{H}), 7.78$ $(\mathrm{t}, J=7.4 \mathrm{~Hz}, 1 \mathrm{H}), 7.55(\mathrm{t}, J=7.4 \mathrm{~Hz}, 1 \mathrm{H}), 7.17(\mathrm{~d}, J=8.7 \mathrm{~Hz}, 2 \mathrm{H}), 6.82(\mathrm{~d}, J=8.7 \mathrm{~Hz}, 2 \mathrm{H}), 5.98(\mathrm{~s}, 1 \mathrm{H}), 5.35(\mathrm{~s}, 1 \mathrm{H})$, 3.79 (s, 3H) $\mathrm{OH}$ not seen. ${ }^{13} \mathrm{C} \mathrm{NMR}\left(75 \mathrm{MHz}, \mathrm{CDCl}_{3}\right) \delta 164.5,160.0,152.3,146.3,145.8,145.0,132.1,131.0,129.8$, 129.1, 129.0, 128.0 (2), 126.6, 119.9, 116.6, 114.2 (2), 55.5. IR (neat) $v_{\max } / \mathrm{cm}^{-1}: 3291,2959,1696,1606,1511,1441$, 1250. HRMS calcd for $\mathrm{C}_{19} \mathrm{H}_{16} \mathrm{NO}_{3}[\mathrm{M}+\mathrm{H}]^{+} 306.1130$, obsd. 306.1134 .

4.2.6. Methyl 4-(1-(4-methoxyphenyl)vinyl)quinoline-2-carboxylate $\mathbf{2 i}$ (100\%).

At $-5{ }^{\circ} \mathrm{C}$ were successively added in $\mathrm{MeOH}(1 \mathrm{~mL}), \mathrm{SOCl}_{2}(72 \mathrm{~mL}, 1 \mathrm{mmol})$, and after $30 \mathrm{~min}$ amide $\mathbf{2 g}(171 \mathrm{mg}, 0.62$ mmol). The solution was then stirred at $55^{\circ} \mathrm{C}$ for $6 \mathrm{~h}$. After cooling to rt, the solution was concentrated and water and EtOAc were added to the crude. After extraction and drying on $\mathrm{Na}_{2} \mathrm{SO}_{4}$, the residue was purified by silica gel column chromatography to give $\mathbf{2 i}(203 \mathrm{mg}, 100 \%)$.

Pale yellow solid, $\mathrm{F}=94.2-94.9{ }^{\circ} \mathrm{C} .{ }^{1} \mathrm{H}$ NMR $\left(300 \mathrm{MHz}, \mathrm{CDCl}_{3}\right) \delta 8.33(\mathrm{~d}, J=8.0 \mathrm{~Hz}, 1 \mathrm{H}), 8.13(\mathrm{~s}, 1 \mathrm{H}), 7.83(\mathrm{~d}, J=$ $8.0 \mathrm{~Hz}, 1 \mathrm{H}), 7.73(\mathrm{t}, J=7.5 \mathrm{~Hz}, 1 \mathrm{H}), 7.49(\mathrm{t}, J=7.5 \mathrm{~Hz}, 1 \mathrm{H}), 7.18(\mathrm{~d}, J=8.9 \mathrm{~Hz}, 2 \mathrm{H}), 6.81(\mathrm{~d}, J=8.9 \mathrm{~Hz}, 2 \mathrm{H}), 5.96(\mathrm{~s}$, 1H), $5.34(\mathrm{~s}, 1 \mathrm{H}), 4.09$ (s, 3H), $3.78(\mathrm{~s}, 3 \mathrm{H}) .{ }^{13} \mathrm{C} \mathrm{NMR}\left(75 \mathrm{MHz}, \mathrm{CDCl}_{3}\right) \delta 166.2,159.9,150.4,148.1,147.9,145.2$, 132.3, 131.1, 130.2, 128.6, 128.4, 128.0 (2), 126.2, 121.7, 116.0, 114.2 (2), 55.4, 53.3. IR (neat) $v_{\max } / \mathrm{cm}^{-1}: 3001,2952$, 1720, 1605, 1511, 1414, 1249. HRMS calcd for $\mathrm{C}_{20} \mathrm{H}_{18} \mathrm{NO}_{3}[\mathrm{M}+\mathrm{H}]^{+} 320.1287$, obsd. 320.1278 .

4.2.7. 4-(1-(4-Methoxyphenyl)vinyl)quinoline-2-carbaldehyde $\mathbf{2 j}$ (69\%, sensitive compound which must be used rapidly after purification)

At $-78{ }^{\circ} \mathrm{C}$ under argon, was added a $1 \mathrm{~N}$ solution of DIBAL $(0.06 \mathrm{~mL})$ to a $\mathrm{CH}_{2} \mathrm{Cl}_{2}$ solution $(1 \mathrm{~mL})$ of $2 \mathbf{i}(20 \mathrm{mg}, 0.06$ $\mathrm{mmol})$. The mixture was stirred at this temperature for $0.5 \mathrm{~h}$ and quenched with $\mathrm{MeOH}(5 \mathrm{~mL})$. After concentration, the crude was purified by silica gel column chromatography to give $\mathbf{2 j}$ ( $17 \mathrm{mg}, 69 \%$ ). 
White solid. $\mathrm{F}=105.3-106.0{ }^{\circ} \mathrm{C}{ }^{1} \mathrm{H}$ NMR $\left(300 \mathrm{MHz}, \mathrm{CDCl}_{3}\right) \delta 10.27(\mathrm{~s}, 1 \mathrm{H}), 8.28(\mathrm{~d}, J=8.5 \mathrm{~Hz}, 1 \mathrm{H}), 7.96(\mathrm{~s}, 1 \mathrm{H})$, $7.85(\mathrm{~d}, J=8.5 \mathrm{~Hz}, 1 \mathrm{H}), 7.76(\mathrm{t}, J=8.2 \mathrm{~Hz}, 1 \mathrm{H}), 7.53(\mathrm{t}, J=8.2 \mathrm{~Hz}, 1 \mathrm{H}), 7.18(\mathrm{~d}, J=8.8 \mathrm{~Hz}, 2 \mathrm{H}), 6.81(\mathrm{~d}, J=8.8 \mathrm{~Hz}$, 2H), $5.96(\mathrm{~s}, 1 \mathrm{H}), 5.34(\mathrm{~s}, 1 \mathrm{H}), 3.79$ (s, 3H). ${ }^{13} \mathrm{C} \mathrm{NMR}\left(75 \mathrm{MHz}, \mathrm{CDCl}_{3}\right) \delta 194.1,159.9,152.5,150.5,148.5,145.3$, $132.3,130.9,130.4,129.2,128.0(2), 126.6,126.3,118.0,116.2,114.2(2), 55.5$.

\subsection{8. (4-(1-(4-Methoxyphenyl)vinyl)quinolin-2-yl)methanol $\mathbf{2 k}(66 \%)$}

$\mathbf{2 k}$ was prepared according to the same reducing protocole used for the synthesis of $\mathbf{2} \mathbf{j}$

Brown oil. ${ }^{1} \mathrm{H}$ NMR $\left(300 \mathrm{MHz}, \mathrm{CDCl}_{3}\right) \delta 8.11(\mathrm{~d}, J=7.6 \mathrm{~Hz}, 1 \mathrm{H}), 7.76(\mathrm{~d}, J=7.6 \mathrm{~Hz}, 1 \mathrm{H}), 7.68(\mathrm{t}, J=7.6 \mathrm{~Hz}, 1 \mathrm{H})$, $7.39(\mathrm{t}, J=7.6 \mathrm{~Hz}, 1 \mathrm{H}), 7.32-7.15(\mathrm{~m}, 3 \mathrm{H}), 6.81(\mathrm{~d}, J=8.9 \mathrm{~Hz}, 2 \mathrm{H}), 5.93(\mathrm{~s}, 1 \mathrm{H}), 5.30(\mathrm{~s}, 1 \mathrm{H}), 4.95(\mathrm{~s}, 2 \mathrm{H}), 3.78(\mathrm{~s}$, 3H) $3.46(\mathrm{~s}, 1 \mathrm{H}) .{ }^{13} \mathrm{C} \mathrm{NMR}\left(75 \mathrm{MHz}, \mathrm{CDCl}_{3}\right) \delta 159.8,158.8,149.9,147.1,145.5,132.3,129.8,128.9,128.0$ (2), 126.7 , 126.4 (2), 118.9, 115.5, 114.1 (2), 64.2, 55.4. IR (neat) $v_{\max /} \mathrm{cm}^{-1}: 3056,2789,2289,1615,1579,1535,1412,1270$. HRMS calcd for $\mathrm{C}_{19} \mathrm{H}_{18} \mathrm{NO}_{2}[\mathrm{M}+\mathrm{H}]^{+} 292.1338$, obsd. 292.1343 .

\subsubsection{N-(4-methoxyphenyl)-N-methyl-2-(trifluoromethyl)quinolin-4-amine $2 \mathbf{l}(92 \%)$}

In a sealed tube and under an argon atmosphere were added successively, 4-chloro-2-(trifluoromethyl)quinoline 5 (232 $\mathrm{mg}, 1 \mathrm{mmol})$, hydrazone 3a (478 mg, $1.5 \mathrm{mmol}) \mathrm{PdCl}_{2}\left(\mathrm{CH}_{3} \mathrm{CN}\right)_{2}(26 \mathrm{mg}, 10 \mathrm{~mol} \%)$, dppf (111 mg, $\left.20 \mathrm{~mol} \%\right) \mathrm{in} \mathrm{dry}$ dioxane $(10 \mathrm{~mL})$ and the mixture was stirred for $5 \mathrm{~min}$. at rt. Then dry $\mathrm{LiO} t \mathrm{Bu}(176 \mathrm{mg}, 2.2 \mathrm{mmol})$ was added and the mixture was stirred at $100^{\circ} \mathrm{C}$ for $3 \mathrm{~h}$. The resulting suspension was cooled to room temperature, filtered through a pad of Celite eluting with ethyl acetate and the inorganic salts were removed. The filtrate was concentrated and the crude was purified by silica gel column chromatography (Cyclohexane/AcOEt, 95/5) to give 21 (303 mg, 0.92 mmol, $92 \%$ ).

Brown oil. ${ }^{1} \mathrm{H}$ NMR $\left(300 \mathrm{MHz} \mathrm{CDCl}_{3}\right) \delta 8.07(\mathrm{~d}, J=8.5 \mathrm{~Hz}, 1 \mathrm{H}), 7.67(\mathrm{~d}, J=8.5 \mathrm{~Hz}, 1 \mathrm{H}), 7.58(\mathrm{t}, J=7.7 \mathrm{~Hz}, 1 \mathrm{H})$, $7.49(\mathrm{~s}, 1 \mathrm{H}), 7.33(\mathrm{t}, J=7.7 \mathrm{~Hz}, 1 \mathrm{H}), 7.00(\mathrm{~d}, J=8.5 \mathrm{~Hz}, 2 \mathrm{H}), 6.64(\mathrm{~d}, J=8.5 \mathrm{~Hz}, 2 \mathrm{H}), 5.80(\mathrm{~s}, 1 \mathrm{H}), 5.16(\mathrm{~s}, 1 \mathrm{H}), 3.61$ (s, 3H). ${ }^{13} \mathrm{C}$ NMR $\left(75 \mathrm{MHz}, \mathrm{CDCl}_{3}\right) \delta 158.8,150.2,146.7(\mathrm{q}, J=38 \mathrm{~Hz}) 146.5,143.8(2), 130.8,129.5,129.3,127.4$, 126.8 (2), 125.2, 120.6 (q, $J=274 \mathrm{~Hz}), 116.2,115.1,113.0(2), 54.3 .{ }^{19} \mathrm{~F}$ NMR (188 MHz, $\left.\mathrm{CDCl}_{3}\right) \delta-68.2 . \mathrm{IR}$ (neat) $v_{\max } / \mathrm{cm}^{-1}: 2961,2904,2358,1606,1511,1442,1419,1382,1341,1250,1179,1033$. HRMS calcd for $\mathrm{C}_{19} \mathrm{H}_{15} \mathrm{NOF}_{3}[\mathrm{M}$ $+\mathrm{H}]^{+} 330.1106$ found 330.1110 .

\subsubsection{0. (4-Methoxyphenyl)(2-methylquinolin-4-yl)-methanone 6 (49\%)}

Into a three neck round bottom flask provided with a drying tube and a gas dispersion tube, a solution of $\mathbf{2 a}(874 \mathrm{mg}$, $3.15 \mathrm{mmol}$ ) in $50 \mathrm{~mL}$ of a mixture of $\mathrm{CH}_{2} \mathrm{Cl}_{2} / \mathrm{MeOH}(9 / 1)$ was prepared. The solution was then cooled to $-78{ }^{\circ} \mathrm{C}$ and saturated with $\mathrm{O}_{2}$. Then, a stream of $\mathrm{O}_{3} / \mathrm{O}_{2}$ (approximately $1 \%$ of $\mathrm{O}_{3}$ ) was applied to the solution. After 15 min, the mixture become green-blue. The ozonizer was set to $0 \mathrm{~V}$, and the solution was purged with $\mathrm{O}_{2}$ for 15 min. After disappearance of $\mathbf{2 a}$ (judged by TLC), $\mathrm{PPh}_{3}(1.65 \mathrm{~g}, 6.30 \mathrm{mmol})$ was added by small portions at $-78{ }^{\circ} \mathrm{C}$. After $4 \mathrm{~h}$ of stirring, the reaction mixture was returned to $\mathrm{rt}$ and $\mathrm{PPh}_{3}(826 \mathrm{mg}, 3.15 \mathrm{mmol})$ was added again. The resulting orange solution was stirred overnight and concentrated under reduced pressure. The crude residue was purified by chromatography on silica gel (Cyclohexane/AcOEt, 8/2 to 4/6) to give $431 \mathrm{mg}$ of 5 (1.54 mmol, $49 \%$ ).

Brown solid, F: $121-124{ }^{\circ} \mathrm{C} .{ }^{1} \mathrm{H}$ NMR $\left(300 \mathrm{MHz} \mathrm{CDCl}_{3}\right) \delta 8.01(\mathrm{~d}, J=8.4 \mathrm{~Hz}, 1 \mathrm{H}), 7.73(\mathrm{~d}, J=8.9 \mathrm{~Hz}, 2 \mathrm{H}), 7.66(\mathrm{~d}, J$ $=9.2 \mathrm{~Hz}, 1 \mathrm{H}), 7.60(\mathrm{dd}, J=8.3 \mathrm{~Hz}, J=1.2 \mathrm{~Hz}, 1 \mathrm{H}), 7.35(\mathrm{t}, J=7.6 \mathrm{~Hz}, 1 \mathrm{H}), 7.18(\mathrm{~s}, 1 \mathrm{H}), 6.84(\mathrm{~d}, J=8.9 \mathrm{~Hz}, 2 \mathrm{H})$, $3.78(\mathrm{~s}, 3 \mathrm{H}), 2.70(\mathrm{~s}, 3 \mathrm{H}) .{ }^{13} \mathrm{C} \mathrm{NMR}\left(75 \mathrm{MHz}, \mathrm{CDCl}_{3}\right) \delta 194.8,164.6,158.4,148.3,145.5,132.80$ (2), $130.0,129.8$, 129.2, 126.6, 125.4, 123.5, 120.1, 114.1 (2), 55.7, 25.5. IR (neat) $v_{\max } / \mathrm{cm}^{-1}: 1731,1657,1597,1511,1462,1422,1379$, 1342, 1250, 1170, 1029. HRMS calcd for $\mathrm{C}_{20} \mathrm{H}_{16} \mathrm{NO}_{2}[\mathrm{M}+\mathrm{H}]^{+} 278.1181$ found 278.1179. 
A $1.0 \mathrm{M}$ solution of LiHMDS $(1.20 \mathrm{~mL}, 1.20 \mathrm{mmol})$ was added dropwise to a cooled $\left(0{ }^{\circ} \mathrm{C}\right)$ solution of diethyl (cyanomethyl)phosphonate $(213 \mathrm{mg}, 1.20 \mathrm{mmol})$ in dry THF $(5 \mathrm{~mL})$. The yellow reaction mixture was returned to $\mathrm{rt}$ and was stirred for 45 minutes. Then, a solution of 5 (166 mg, $0.60 \mathrm{mmol})$ in THF (5 mL) was slowly cannulated into the ylide solution. After $15 \mathrm{~min}$. of stirring, the reaction flask was heated to reflux for $12 \mathrm{~h}$, and was then cooled to rt. The reaction was quenched using $\mathrm{H}_{2} \mathrm{O}(20 \mathrm{~mL})$, and the solvent was removed under vacuum. After extraction with AcOEt $(3 \times 10 \mathrm{~mL})$, the organic phase was washed with brine $(15 \mathrm{~mL})$, dried over $\mathrm{MgSO}_{4}$ and concentrated. The crude residue was purified by chromatography on silica gel (Cyclohexane/AcOEt, 8/2 to 4/6) to afforded $90 \mathrm{mg}$ of $\mathbf{2 m}(0.30$ mmol, $50 \%)$ as a mixture of inseparable diastereoisomers $(E / Z=62 / 38)$.

White solid, F: $134-137{ }^{\circ} \mathrm{C} .{ }^{1} \mathrm{H}$ NMR $\left(300 \mathrm{MHz}, \mathrm{CDCl}_{3}\right) \delta 8.10(\mathrm{t}, J=9.9 \mathrm{~Hz}, 1 \mathrm{H}), 7.76-7.64(\mathrm{~m}, 1 \mathrm{H}), 7.62-7.49(\mathrm{~m}$, $1.7 \mathrm{H}), 7.40(\mathrm{t}, J=7.1 \mathrm{~Hz}, 1 \mathrm{H}), 7.32-7.20(\mathrm{~m}, 2.3 \mathrm{H}), 6.92(\mathrm{~d}, J=8.9 \mathrm{~Hz}, 0.76 \mathrm{H}), 6.86(\mathrm{~d}, J=8.9 \mathrm{~Hz}, 1.24 \mathrm{H}), 6.11(\mathrm{~s}$, $0.62 \mathrm{H}), 5.56(\mathrm{~s}, 0.38 \mathrm{H}), 3.85(\mathrm{~s}, 1.14 \mathrm{H}), 3.82(\mathrm{~s}, 1.86 \mathrm{H}), 2.84(\mathrm{~s}, 1.86 \mathrm{H}), 2.80(\mathrm{~s}, 1.14 \mathrm{H}) .{ }^{13} \mathrm{C} \mathrm{NMR}(75 \mathrm{MHz}$, $\left.\mathrm{CDCl}_{3}\right) \delta 162.1,161.7,159.0,158.9,158.8,158.7,148.5,146.4,143.7,130.6,130.0,129.9,129.5,129.4,129.0,128.9$, 126.6, 125.2, 125.0, 124.4, 124.3, 122.3, 122.1, 117.6, 117.1, 114.7, 114.4, 96.3, 95.4, 55.6, 55.5, 25.5, 25.4. IR (neat) $v_{\max } / \mathrm{cm}^{-1}: 2925,2851,2214,1603,1512,1449,1359,1299,1256,1179,1029$. HRMS calcd for $\mathrm{C}_{20} \mathrm{H}_{17} \mathrm{NO}_{2}\left[\mathrm{M}+\mathrm{H}^{+}\right.$ 301.1341 obsd. 301.1335 .

\subsubsection{1-(1-(4-Methoxyphenyl)vinyl)-3-methylnaphthalene $\mathbf{2 n}(79 \%)$}

A $20 \mathrm{~mL}$ microwave tube containing a stir bar was charged with 1-bromo-3-methylnaphthalene (221 mg, $1.0 \mathrm{mmol}, 1.0$

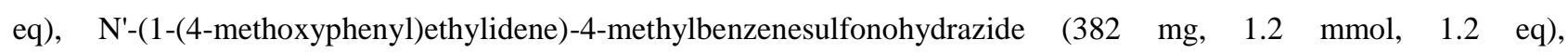
$\mathrm{Pd}_{2} \mathrm{dba}_{3} . \mathrm{CHCl}_{3}(26 \mathrm{mg}, 2.5 \mathrm{~mol} \%$ ), XPhos (48 mg, $10 \mathrm{~mol} \%$ ) and lithium tert-butoxide (176 mg, $2.2 \mathrm{mmol}, 2.2 \mathrm{eq}$ ). The tube was capped and purged with argon three time, then dioxane $(5-10 \mathrm{~mL})$ was added via syringe. After sealing the tube, it was put into a pre-heated oil bath at $100{ }^{\circ} \mathrm{C}$ and stirred for $2 \mathrm{~h}$. Then, the reaction mixture was allowed to cool to rt and EtOAc was added to the mixture, which was filtered through Celite. The solvents were evaporated under reduce pressure and the crude residue was purified by flash chromatography on silica gel (Cyclohexane/AcOEt 10/0 to $7 / 3)$ to give $2 \mathbf{n} 216 \mathrm{mg}(0.79 \mathrm{mmol}, 79 \%)$.

Yellow oil. ${ }^{1} \mathrm{H}$ NMR $\left(300 \mathrm{MHz}, \mathrm{CDCl}_{3}\right) \delta(\mathrm{ppm}) 7.84(\mathrm{dd}, J=8.1 \mathrm{~Hz}, J=5.0 \mathrm{~Hz}, 2 \mathrm{H}), 7.70(\mathrm{~s}, 1 \mathrm{H}), 7.53-7.42(\mathrm{~m}, 1 \mathrm{H})$, 7.39-7.32 (m, 3H), $6.87(\mathrm{~d}, J=8.8 \mathrm{~Hz}, 2 \mathrm{H}), 5.96(\mathrm{~s}, 1 \mathrm{H}), 5.37(\mathrm{~s}, 1 \mathrm{H}), 3.82(\mathrm{~s}, 3 \mathrm{H}), 2.61(\mathrm{~s}, 3 \mathrm{H}) .{ }^{13} \mathrm{C} \mathrm{NMR}(75 \mathrm{MHz}$, $\left.\mathrm{CDCl}_{3}\right) \delta(\mathrm{ppm})$ 159.3, 147.7, 140.0, 135.1, 134.1, 133.8, 130.3, 129.4, 127.9 (2), 127.6, 126.9, 126.4, 125.8, 125.1, 114.2, 113.8 (2), 55.3, 21.7. IR (neat) $v_{\max } / \mathrm{cm}^{-1}: 2959,2834,1604,1509,1462,1441,1342,1290,1246,1177,1117$, 1097, 1033. HRMS (ESI) calcd for $\mathrm{C}_{20} \mathrm{H}_{19} \mathrm{O}(\mathrm{M}+\mathrm{H})^{+} 275.1536$ obsd. 275.1527.

\subsection{Biolology}

\subsubsection{Cell Culture and Proliferation Assay}

Cancer cell lines were obtained from the American type Culture Collection (Rockville, MD) and were cultured according to the supplier's instructions. Briefly, U87, K562, K562R and HCT116 cells were grown in RPMI 1640 containing 10\% FCS and 1\% glutamine. A549 lung carcinoma, cells were grown in Dulbecco minimal essential medium (DMEM) containing $4.5 \mathrm{~g} / \mathrm{L}$ glucose supplemented with $10 \%$ FCS and $1 \%$ glutamine.

All cell lines were maintained at $37{ }^{\circ} \mathrm{C}$ in a humidified atmosphere containing $5 \% \mathrm{CO}_{2}$. Cell viability was assessed using Promega CellTiter-Blue TM reagent according to the manufacturer's instructions. Cells were seeded in 96-well plates $(5 \times 103$ cells/well) containing $50 \mu \mathrm{L}$ growth medium. After $24 \mathrm{~h}$ of culture, the cells were supplemented with 50 $\mu \mathrm{L}$ of the tested compound dissolved in DMSO (less than $0.1 \%$ in each preparation). After $72 \mathrm{~h}$ of incubation, $20 \mu \mathrm{L}$ of resazurin was added for $2 \mathrm{~h}$ before recording fluorescence $(\lambda \mathrm{ex}=560 \mathrm{~nm}, \lambda \mathrm{em}=590 \mathrm{~nm})$ using a Victor microtiter plate fluorimeter (Perkin-Elmer, USA). The $\mathrm{IC}_{50}$ corresponds to the concentration of the tested compound that caused a 
decrease of $50 \%$ in fluorescence of drug treated cells compared with untreated cells. Experiments were performed in triplicate.

\subsubsection{Tubulin Binding Assay}

Sheep brain tubulin was purified according to the method of Shelanski [33] by two cycles of assembly-disassembly and then dissolved in the assembly buffer containing 0.1 M MES, $0.5 \mathrm{mM} \mathrm{MgCl}, 1 \mathrm{mM}$ EGTA, and $1 \mathrm{mM}$ GTP, pH 6.6 (the concentration of tubulin was about $2-3 \mathrm{mg} / \mathrm{mL}$ ). Tubulin assembly was monitored by fluorescence according to reported procedure [34] using DAPI as fluorescent molecule. Assays were realized on 96-well plates prepared with Biomek NKMC and Biomek 3000 from Beckman Coulter and read at $37^{\circ} \mathrm{C}$ on Wallac Victor fluorimeter from Perkin Elmer. The $\mathrm{IC}_{50}$ value of each compound was determined as the concentration which decreased the maximum assembly rate of tubulin by $50 \%$ compared to the rate in the absence of compound. The $\mathrm{IC}_{50}$ values for all compounds were compared to the $\mathrm{IC}_{50}$ of $i s o \mathrm{CA}-4$ and measured the same day under the same conditions.

\subsubsection{Cell Cycle Analysis}

Exponentially growing cancer A549 cells were incubated with $\mathbf{2 b}$ at different concentrations $(0.5,1,5 \mathrm{and} 10 \mathrm{nM})$ or in DMSO alone for $24 \mathrm{~h}$. Cell-cycle profiles were determined by flow cytometry on a FC500 flow cytometer (BeckmanCoulter, France) as described previously. [35]

\subsubsection{Immunofluorescence Staining Assays}

A549 cells were seeded on Lab-Tek ${ }^{\mathrm{TM}}$ Chamber Slides (Thermo Fisher Scientific) and incubated for $24 \mathrm{~h}$ in the presence or absence $\mathbf{2 b}$. Cells were then fixed for $30 \mathrm{~min}$. with $2 \%$ paraformaldehyde at room temperature and washed with Dulbecco's phosphate-buffered saline (DPBS).

After permeabilization with $0.25 \%$ Triton X-100 for 5 min., A549 cells were washed in DPBS and incubated for $1 \mathrm{~h}$ in DPBS containing 1\% Bovine Serum Albumine (BSA) and 10\% normal goat serum (DAKO cytomation) for blocking. Cells were then incubated overnight at $4{ }^{\circ} \mathrm{C}$ with the mouse anti- $\beta$ tubulin primary antibody (Thermo Fisher Scientific). Thereafter, the cells were washed with $0.2 \%$ Tween in DPBS, and incubated simultaneous for $2 \mathrm{~h}$ at room temperature with Alexa-Fluor ${ }^{\circledR} 647$ goat anti-mouse IgG secondary antibody and Hoechst 33258 (Thermo Fisher Scientific). Cells were then washed with DPBS and incubated for $30 \mathrm{~min}$ at room temperature with Alexa-Fluor 488 Phalloidin (Thermo Fisher Scientific) to perform F-actin labeling. Fluorescence images were collected by Nikon TE2000 inverted microscope with Nikon 1.4 NA DIC optics, 60X oil immersion objective (Nikon).

\subsubsection{Molecular Modelling}

X-ray structures of five different tubulin co-crystals were retrieved from the PDB [36] (accession codes 1SA0, 1SA1, 3HKC, 3HKD, and 3HKE) and prepared using the Protein Preparation Wizard workflow from Schrödinger suite, [37] including optimization of the hydrogen bond network and a short energy minimization with position restraints on heavy atoms using the OPLS_2005 force field. [38] Initial coordinates for compounds 2a,b and 2d-f were generated using MarvinSketch from JChem suite v15.12.7, [39]. Ligands were then freely docked in the colchicine binding site located between chains $\mathrm{C}$ and D using the ensemble docking procedure available in GOLD v5.2.2 [40] over the five (aligned) tubulin structures. CHEMPLP with default parameters was used as an objective function.[41] Structures of the complexes were exported, subjected to hydrogen bond network optimization, and a short minimization with position restraints on heavy atoms using Protein Preparation Wizard, then loaded into Chimera v1.10.2 [42] for examination (including hydrogen bond detection, close contact analysis, and representation of solvent-accessible surface) and depiction. 


\section{Acknowledgments}

The CNRS (Centre National de la Recherche Scientifique) is gratefully acknowledged for financial support of this research. Our laboratory BioCIS-UMR 8076 is a member of the Laboratory of Excellence LERMIT supported by a grant from ANR (Agence Nationale de la Recherche, ANR-10-LABX-33).

The authors gratefully acknowledge support of this project by CNRS, University Paris-Sud and "La Ligue Contre le Cancer" throughout an "Équipe Labellisée 2014" grant. Our laboratory (BioCIS UMR 8076) is a member of the laboratory of excellence LERMIT supported by a grant from ANR (ANR-10-LABX-33).

\section{References}

[1] G. R. Pettit, S. B. Singh, E. Hamel, C. M. Lin, D. S. Alberts, D. Garcia-Kendall, Isolation and structure of the strong cell growth and tubulin inhibitor combretastatin A-4, Experientia 45 (1989) 209-211.

[2] C. M. Lin, H. H. Ho, G. R. Pettit, E. Hamel, Antimitotic natural products combretastatin A-4 and combretastatin A-2: studies on the mechanism of their inhibition of the binding of colchicine to tubulin, Biochemistry 28 (1989) 6984-6991.

[3] A. T. Mc Gown, B. W. Fox, Differential cytotoxicity of combretastatins A1 and A4 in two daunorubicin-resistant P388 cell lines, Cancer Chemother. Pharmacol. 26 (1990) 79-81.

[4] G. G. Dark, S. A. Hill, V. E. Prise, G. M. Tozer, G. R. Pettit, D. J. Chaplin, Combretastatin A-4, an agent that displays potent and selective toxicity toward tumor vasculature, Cancer Res. 57 (1997) 1829-1834.

[5] S. L. Young, D. J. Chaplin, Combretastatin A4 phosphate: background and current clinical status, Expert Opin. Investig. Drugs 13 (2004) 1171-1182.

[6] www.mateon.com

[7] K. Ohsumi, T. Hatanaka, R. Fujita, R.Nakagawa, Y. Fukuda, Y. Nihei, Y. Suga, Y. Morinaga, Y. Akiyama, T. Tsuji, Syntheses and antitumor activity of cis-restricted combretastatins: 5-membered heterocyclic analogues, Bioorg. Med. Chem. Lett. 8 (1998) $3153-3158$.

[8] S. Aprile, E. Del Grosso, G. C. Tron, G. Grosa, Identification of the Human UDP-Glucuronosyltransferases Involved in the Glucuronidation of Combretastatin A-4, Drug Metab. Dispos. 35 (2007) 2252-2261.

[9] G. C. Tron, T. Pirali, G. Sorba, F. Pagliai, S. Busacca, A. A. Genazzani, Medicinal chemistry of combretastatin A4: present and future directions, J. Med. Chem. 49 (2006), 3033-3044.

[10] M. Marelli, F. Conforti, G. A. Statti, X. Cachet, S. Michel, F. Tillequin, F. Menichini, Biological potential and structure-activity relationships of most recently developed vascular disrupting agents: an overview of new derivatives of natural combretastatin A-4, Curr. Med. Chem. 18 (2011), 3035-3081.

[11] O. Provot, A. Hamze, J. F. Peyrat, J. D. Brion, M. Alami, Discovery and Hit to Lead Optimization of Novel Combretastatin A-4 Analogues: Dependence of C-Linker Length and Hybridization, Anticancer Agents Med. Chem. 13 (2013) 1614-1635.

[12] S. Messaoudi, B. Tréguier, A. Hamze, O. Provot, J. F. Peyrat, J. R. Rodrigo De Losada, J. M. Liu, J. Bignon, J. Wdzieczak-Bakala, S. Thoret, J. Dubois, J. D. Brion, M. Alami, Isocombretastatins A versus Combretastatins A: The Forgotten isoCA-4 Isomer as a Highly Promising Cytotoxic and Antitubulin Agent, J. Med. Chem. 52 (2009) 4538-4542.

[13] A. Hamze, A. Giraud, S. Messaoudi, O. Provot, J. F. Peyrat, J. Bignon, J. M. Liu, J. Wdzieczak-Bakala, S. Thoret, J. Dubois, J. D. Brion, M. Alami, Synthesis, Biological Evaluation of 1,1-Diarylethylenes as a Novel Class of Antimitotic Agents, ChemMedChem 4 (2009) 1912-1924.

[14] For example, isoCA-4 is stable 8 days in $\mathrm{HCl} 12 \mathrm{~N}$ on the contrary of CA-4 which rapidely isomerize into its $(E)$-isomer

[15] M. A. Soussi, S. Aprile, S. Messaoudi, O. Provot, E. Del Grosso, J. Bignon, J. Dubois, J. D. Brion, G. Grosa, M. Alami, The Metabolic Fate of isoCombretastatin A-4 in Human Liver Microsomes: Identification, Synthesis and Biological Evaluation of Metabolites, ChemMedChem 6 (2011) 1781-1788

[16] A. Hamze, E. Rasolofonjatovo, O. Provot, C. Mousset, D. Veau, J. Rodrigo, J. Bignon, J. M; Liu, J. Wdzieczak-Bakala, S. Thoret, J. Dubois, J. D. Brion, M. Alami, B-Ring-Modified isoCombretastatin A-4 Analogues Endowed with Interesting Anticancer Activities, ChemMedChem 6 (2011) 2179-2191

[17] E. Rasolofonjatovo, O. Provot, A. Hamze, J. Rodrigo, J. Bignon, J. Wdzieczak-Bakala, D. Desravines, J. Dubois, J. D. Brion, M. Alami, Conformationnally restricted naphthalene derivatives type isocombretastatin A-4 and isoerianin analogues: synthesis, cytotoxicity and antitubulin activity, Eur. J. Med. Chem. 52 (2012) 22-32.

[18] D. Renko, E. Rasolofonjatovo, O. Provot, J. Bignon, J. Rodrigo, J. Dubois, J. D. Brion, A. Hamze, M. Alami, Rapid synthesis of 4arylchromenes from ortho-substituted alkynols: A versatile access to restricted isocombretastatin A-4 analogues as antitumor agents, Eur. J. Med. Chem. 90 (2015) 834-844.

[19] E. Rasolofonjatovo, O. Provot, A. Hamze, J. Rodrigo, J. Bignon, J. Wdzieczak-Bakala, C. Lenoir, D. Desravines, J. Dubois, J. D. Brion, M. Alami, Design, synthesis and anticancer properties of 5-arylbenzoxepins as conformationally restricted isocombretastatin A-4 analogs, Eur. J. Med. Chem. 62 (2013) 28-39.

[20] K. Mahal, M. Resch, R. Ficner, R. Schobert, B. Biersack, T. Mueller, Effects of the Tumor-Vasculature-Disrupting Agent Verubulin and Two Heteroaryl Analogues on Cancer Cells, Endothelial Cells and Blood Vessels, ChemMedChem 9 (2014) 847-854.

[21] N. Sirisoma, A. Pervin, H. Zhang, S. Jiang, J. A. Willardsen, M. B. Anderson, G. Mathet, C. M. Pleiman, S. Kasibhatla, B. Tseng, J. Drewe, S. X. Cai, Discovery of $N$-(4-Methoxyphenyl)-N,2-dimethylquinazolin-4-amine, a Potent Apoptosis Inducer and Efficacious Anticancer Agent with High Blood Brain Barrier Penetration, J. Med. Chem. 52 (2009) 2341-2351.

[22] S. Kasibhatla, V. Baichwal, S. X. Cai, B. Roth, I. Skvortsova, S. Skvortsov, P. Lukas, N. E. English, N. Sirisoma, A. Pervin, B. Tseng, R. O. Carlson, C. M. Pleiman, MPC-6827: a small-molecule inhibitor of microtubule formation that is not a substrate for multidrug resistance pumps, Cancer Res. 67 (2007) 5865-5871.

[23] M. A. Soussi,O. Provot, G. Bernadat, J. Bignon, D. Desravines, J. Dubois, J. D. Brion, S. Messaoudi, M. Alami, IsoCombretaQuinazolines: Potent Cytotoxic Agents with Antitubulin Activity, ChemMedChem, 10 (2015) 1392-1402.

[24] In french language, coquine means hussy.

[25] a) E. Rasolofonjatovo, B. Tréguier, O. Provot, A. Hamze, E. Morvan, J. D. Brion, M. Alami, Palladium-Catalyzed Coupling of NTosylhydrazones with ortho Substituted Aryl Halides: Synthesis of 4-Arylchromenes and Related Heterocycles, Tetrahedron Lett. 52 (2011), 1036-1040. b) M. Roche, A Hamze, J. D. Brion, M. Alami, Catalytic Three-Component One-Pot Reaction of Hydrazones, Dihaloarenes, and Amines, Org. Lett. 15 (2013) 148-151. c) E. Brachet, A. Hamze, J. F. Peyrat, J. D. Brion, M. Alami, Pd-Catalyzed Reaction of Sterically Hindered Hydrazones with Aryl Halides: Synthesis of Tetra-Substituted Olefins Related to iso-Combretastatin A4, Org. Lett. 12 (2010) 40424045. d) M. Lawson, A. Hamze, J. F. Peyrat, J. Bignon, J. Dubois, J. D. Brion, M. Alami, An efficient coupling of $N$-tosylhydrazones with $2-$ halopyridines: synthesis of 2- $\alpha$-styrylpyridines endowed with antitumor activity, Org. Biomol. Chem. 11 (2013) 3664-3673. 
[26] For the hydration of nitriles using potassium tert-butoxide see: G.C. Midya, A. Kapat, S. Maiti, J. Dash, Transition-Metal-Free Hydration of Nitriles Using Potassium tert-Butoxide under Anhydrous Conditions, J. Org. Chem. 80 (2015) 4148-4151.

[27] L. C. Li, J. Ren, T. G. Liao, J. X. Jiang, H. J. Zu, A Novel Direct Conversion of Primary Amides to Their Corresponding Methyl Esters, Eur. J. Org. Chem. 72 (2007) 1026-1030.

[28] The ratio of the two isomers was determined by ${ }^{1} \mathrm{H}$ NMR. We did not succeded to separate $(E)$ - and (Z)-isomers which were reported and evaluated together.

[29] Since compound $2 \mathbf{l}$ is present as a inseparable mixture of $(E)$ and $(Z)$-diastereoisomers, we did not continue our investigations with this derivative.

[30] R. B. G. Ravelli, B. Gigant, P. A. Curmi, I. Jourdain, S. Lachkar, A. Sobel, M. Knossow, Insight into tubulin regulation from a complex with colchicine and a stathmin-like domain, Nature 428 (2004) 198-202.

[31] M. A. Soussi, O. Provot, G. Bernadat, J. Bignon, J. Wdzieczak-Bakala, D. Desravines, J. Dubois, J. D. Brion, S. Messaoudi, M. Alami, Discovery of Azaisoerianin Derivatives as Potential Antitumors Agents, Eur. J. Med. Chem. 78 (2014) 178-189.

[32] S. Messaoudi, A. Hamze, O. Provot, B. Tréguier, J. Rodrigo, J. Bignon, J. M. Liu, J. Wdzieczak-Bakala, S. Thoret, J. Dubois, J. D. Brion, M. Alami, Discovery of Isoerianin Analogues as Promising Anticancer Agents, ChemMedChem. 6 (2011) 488-497.

[33] M. L. Shelanski, F. Gaskin, C. R. Cantor, Microtubule Assembly in the Absence of Added Nucleotides, Proc. Natl. Acad. Sci. USA 70 (1973) 765-768.

[34] D. M. Barron, S. K. Chatterjee, R. Ravindra, R. Roof, E. Baloglu, D. G. I. Kingston, S. Bane, A fluorescence-based high-throughput assay for antimicrotubule drugs, Anal. Biochem. 315 (2003) 49-56.

[35] C. Venot, M. Maratrat, C. Dureuil, E. Conseiller, L. Bracco, L. Debussche, The requirement for the p53 proline-rich functional domain for mediation of apoptosis is correlated with specific PIG3 gene transactivation and with transcriptional repression, EMBO J. 17 (1998) $4668-$ 4679.

[36] F. C. Bernstein, T. F. Koetzle, G. J. Williams, E. E. Meyer Jr., M. D. Brice, J. R. Rodgers, O. Kennard, T. Shimanouchi, M. Tasumi, The Protein Data Bank: a computer-based archival file for macromolecular structures, J. Mol. Biol. 11 (1977) 535-542.

[37] a) Protein Preparation Wizard 2013-3; Epik version 2.4; Impact version 5.9; Prime version 3.2, Schrödinger LLC, New York, NY (USA), 2013. b) G. M. Sastry, M. Adzhigirey, T. Day, R. Annabhimoju, W. Sherman, Protein and ligand preparation: parameters, protocols, and influence on virtual screening enrichments, J. Comput.-Aided Mol. Des. 27 (2013) 221-234. c) M. H. M. Olsson, C. R. Søndergard, M. Rostkowski, J. H. Jensen, PROPKA3: Consistent treatment of internal and surface residues in empirical pKa predictions, J. Chem. Theory Comput. 7 (2011) $525-$ 537.

[38] The OPLS 2005 parameters are described, see: J. L. Banks, H. S. Beard, Y. Cao, A. E. Cho, W. Damm, R. Farid, A. K. Felts, T. A. Halgren, D. T. Mainz, J. R. Maple, R. Murphy, D. M. Philipp, M. P. Repasky, L. Y. Zhang, B. J. Berne, R. A. Friesner, E. Gallicchio, R. M. Levy, Integrated Modeling Program, Applied Chemical Theory (IMPACT), J. Comput. Chem. 26 (2005) 1752-1780.

[39] JChem version 15.12.7, 2015, ChemAxon, www.chemaxon.com.

[40] G. Jones, P. Willett, R. C. Glen, A. R. Leach, R. Taylor, Development and validation of a genetic algorithm for flexible docking, J. Mol. Biol. 267 (1997) 727-748.

[41] O. Korb, T. Stützle, T. E. Exner, Empirical scoring functions for advanced protein-ligand docking with PLANTS, J. Chem. Inf. Model. 49 (2009) 84-96.

[42] a) Chimera is developed by the Resource for Biocomputing, Visualization, and Informatics at the University of California, San Francisco (supported by NIGMS P41-GM103311). E. F. Pettersen, T. D. Goddard, C. C. Huang, G. S. Couch, D. M. Greenblatt, E. C. Meng, T. E. Ferrin, UCSF chimera - A visualization system for exploratory research and analysis, J. Comput. Chem. 25 (2004) 1605-1612. b) Solvent-excluded molecular surfaces were created with the help of the MSMS package, see: M. F. Sanner, A. J. Olson, J. C. Spehner, Reduced surface: an efficient way to compute molecular surfaces, Biopolymers 38 (1996) 305-320. 